ARCHIWA - Kancelarie - ZBIORY

NR 6(8)/2015

Hanna Staszewska

Archiwum Państwowe w Poznaniu

WOJCIECH WoźNIAK

Narodowe Archiwum Cyfrowe

\title{
DOKUMENTACJA ELEKTRONICZNA W ARCHIWACH PAŃSTWOWYCH - WYNIKI ANKIETY PRZEPROWADZONEJ W MAJU 2015 R.
}

http://dx.doi.org/10.12775/AKZ.2015.005

Słowa kluczowe

dokument elektroniczny; dokumentacja elektroniczna; archiwa państwowe; badania ankietowe; metodyka archiwalna; cyfryzacja archiwów; digitalizacja materiałów archiwalnych; archiwistyka cyfrowa; informatyczny nośnik danych;

Keywords

electronic record; electronic documentation; state archives; survey; archival methodology; archives computerization; archival materials digitization; digital archivistics; computer data carrier

Streszczenie

Tekst zawiera podsumowanie wyników ankiety przeprowadzonej w dniach 6-29 maja 2015 r. w archiwach państwowych. Celem ankiety było zebranie informacji o ilości 
dokumentacji elektronicznej przechowywanej obecnie w archiwach państwowych, stanie jej zewidencjonowania, opracowania i przechowywania oraz zdiagnozowanie problemów i trudności napotykanych przez archiwistów w pracy z dokumentacją elektroniczną. Wyniki ankiety posłużyć mają do prac analitycznych w zakresie metod i procedur postępowania z dokumentacją elektroniczną.

(0) dokumentacji elektronicznej zwykło się mówić w kontekście ustawy z 17 lutego 2005 r. o informatyzacji działalności podmiotów realizujących zadania publiczne, ponieważ w tym akcie prawnym pojawiła się definicja dokumentu elektronicznego i w wyniku wejścia tej ustawy w życie rozszerzeniu uległa definicja materiałów archiwalnych zawarta w ustawie o narodowym zasobie archiwalnym i archiwach. W konsekwencji dość często pojęcie dokumentu elektronicznego zawężane jest do tych bytów w postaci elektronicznej, które powstały w systemach teleinformatycznych podmiotów realizujących zadania publiczne, w szczególności w systemach elektronicznego zarządzania dokumentacją (systemach EZD). Tymczasem archiwa państwowe przejmują i przechowują coraz więcej dokumentacji elektronicznej, która nie jest efektem funkcjonowania systemów EZD, lecz powstała lub powstaje niezależnie od tych systemów. Jest to dokumentacja, która ma wartość materiałów archiwalnych i jako taka przejmowana jest do zasobu archiwów państwowych. Kiedy więc mowa o dokumentacji elektronicznej w zasobie archiwum państwowego, należy pamiętać nie tylko o dokumentacji, która obecnie powstaje w systemach EZD (lecz jeszcze nie trafiła do żadnego archiwum), ale przede wszystkim należy mieć na względzie dokumentację w postaci elektronicznej, która powstała w odmiennych okolicznościach i nie była zarządzana przez żaden system odpowiedzialny za zarządzanie dokumentacją.

Według rocznych sprawozdań statystycznych KN-1 tworzonych przez Naczelnego Dyrektora Archiwów Państwowych w 2013 r. w archiwach państwowych znajdowało się 16981 dokumentów elektronicznych, a w roku 2014 było ich 19717 (wykres). W ciągu roku przybyło więc w zasobie archiwów 2736 dokumentów elektronicznych, czyli zaledwie $0,37 \%$ ogólnej liczby jednostek archiwalnych, o jakie zwiększył się zasób archiwów w tym okresie. Na koniec roku 2014 większość dokumentacji elektronicznej przechowywanej w archiwach państwowych (ponad 85\%) stanowiły obrazy nieruchome, ponadto na tę część zasobu składały się dokumenty tekstowe $(0,3 \%)$, obrazy 
ruchome $(0,04 \%)$, dokumenty dźwiękowe $(6,9 \%)$ oraz uporządkowane i nieuporządkowane zbiory danych $(7,4 \%)^{1}$.

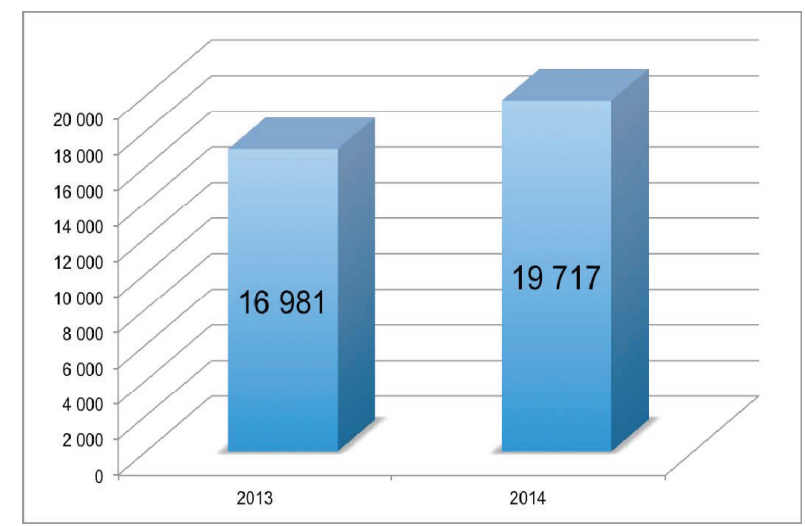

Wykres. Liczba dokumentów elektronicznych wg sprawozdania rocznego KN-1

Celem przeprowadzonej w dniach 6-29 maja 2015 r. ankiety było zebranie informacji o ilości dokumentacji elektronicznej przechowywanej obecnie w archiwach państwowych, stanie jej zewidencjonowania, opracowania i przechowywania oraz zdiagnozowanie problemów i trudności napotykanych przez archiwistów w pracy z dokumentacją elektroniczną. Wyniki ankiety posłużyć mają do prac analitycznych w zakresie metod i procedur postępowania z dokumentacją elektroniczną. Formularze z pytaniami przekazano do 33 archiwów państwowych, ze wszystkich otrzymując odpowiedzi zwrotne. Ankieta opracowana przez Hannę Staszewską (Archiwum Państwowe w Poznaniu) i Wojciecha Woźniaka (Narodowe Archiwum Cyfrowe) składała się z 34 pytań, zarówno zamkniętych, jak i otwartych (treść ankiety - załącznik nr 1 do niniejszego tekstu).

Na potrzeby ankiety przyjęto następujące rozumienie pojęć:

- dokument elektroniczny, dokumentacja w postaci elektronicznej, dokumentacja elektroniczna - zbiór danych zapisany w postaci cyfrowej (tj. w postaci ciągu bitów) na dowolnym informatycznym nośniku danych (np. płycie CD, dysku twardym - HDD, dyskietce elastycznej,

1 Sprawozdania z działalności archiwów państwowych w 2013 i 2014 r., dostęp online, 4.08.2015 r., http://www.archiwa.gov.pl/pl/naczelna-dyrekcja-archiwowpastwowych/224-sprawozdania.html. 
taśmie LTO, serwerze, urządzeniu mobilnym itp.), możliwy do odczytania wyłącznie za pośrednictwem odpowiednich urządzeń elektronicznych; może stanowić zbiór od początku istniejący w postaci elektronicznej (naturalny dokument elektroniczny) lub być kopią elektroniczną dowolnej treści zapisanej w postaci innej niż elektroniczna (odwzorowanie cyfrowe); stanowiący zasób archiwum państwowego (jako samodzielny dokument lub jako załącznik do dokumentacji tradycyjnej) i niebędący kopią tradycyjnych materiałów przechowywanych $\mathrm{w}$ tym archiwum (np. nie jest produktem prowadzonego $\mathrm{w}$ archiwum procesu digitalizacji), choć może być kopią dokumentacji tradycyjnej przechowywanej u innego przechowawcy lub wytwórcy dokumentacji. Do uznania zbioru danych za dokument elektroniczny nie jest wymagana żadna forma jego uwierzytelnienia (np. podpis elektroniczny);

- metadane - zestaw usystematyzowanych informacji, logicznie powiązanych z przesyłką, sprawą lub inną dokumentacją, ułatwiających ich wyszukiwanie, kontrolę, zrozumienie i długotrwałe przechowanie oraz zarządzanie ${ }^{2}$.

Wyniki ankiety ${ }^{3}$ wskazują, że 17 spośród 33 archiwów deklaruje posiadanie w zasobie dokumentacji elektronicznej. Należy przy tym zaznaczyć, że z wyżej przywołanych sprawozdań statystycznych wynika, że na koniec 2014 r. jedynie $10 \mathrm{z}$ nich posiadało dokumentację elektroniczną. Rozbieżność może wynikać z faktu precyzyjnego zdefiniowania dla celów ankiety pojęcia dokumentu elektronicznego, zwłaszcza wskazania, że za takowy uznawane są kopie cyfrowe materiałów archiwalnych, które są przechowywane przez innego niż archiwum przechowawcę lub wytwórcę. Kopie te mogły nie być wykazywane w sprawozdaniach archiwów, lub mogły nie zostać wprowadzone do ewidencji archiwum z różnych przyczyn. Możliwe są i inne przyczyny rozbieżności, ale ten aspekt nie był badany i może zostać wyjaśniony na etapie dalszych prac nad zagadnieniem.

2 Rozporządzenie Prezesa Rady Ministrów z dnia 18 stycznia 2011 r. w sprawie instrukcji kancelaryjnej, jednolitych rzeczowych wykazów akt oraz instrukcji w sprawie organizacji i zakresu działania archiwów zakładowych (Dz.U. 2011, Nr 14, poz. 67).

3 Szczegółowe zestawienie odpowiedzi na poszczególne pytania zawiera załącznik nr 2 do niniejszego tekstu. 
Dokumentacja elektroniczna przejmowana jest przez archiwa państwowe od 2006 r. ${ }^{4}$ Lata, w których po raz pierwszy zarejestrowano przejęcia dokumentacji elektronicznej, obrazuje poniższe zestawienie:

\begin{tabular}{|l|l|}
\hline \hline ROK PRZEJĘCIA & \multicolumn{1}{|c|}{ ARCHIWUM } \\
\hline \hline 2006 & AP Częstochowa, Warszawa \\
\hline 2007 & AP Olsztyn, Płock \\
\hline 2009 & NAC, AP Elbląg \\
\hline 2010 & AP Radom \\
\hline 2011 & AP Lublin \\
\hline 2012 & AP Suwałki \\
\hline 2013 & AN Kraków, AP Szczecin \\
\hline 2014 & AP Zielona Góra, AAN \\
\hline 2015 & AP Poznań \\
\hline
\end{tabular}

Wśród przejętej dokumentacji znajduje się 15 zespołów złożonych wyłącznie z dokumentacji elektronicznej (w tym m.in. Dokumentacja tzw. śledztwa katyńskiego - sprawy karnej nr 159 Prokuratury Generalnej - AAN, Zbiór filmów związanych z Krakowem, Archiwum Studia TVS Wiesława Szkarłata z Nowego Sącza - ANK, Katolickie Radio Płock - audycje radiowe Poranny Gość - AP Płock). Pozostała dokumentacja elektroniczna została włączona do istniejących już zespołów lub przejęta razem z dokumentacją tradycyjną, co w efekcie daje 39 zespołów złożonych zarówno z dokumentacji elektronicznej, jak i tradycyjnej (w tym m.in. Akta komisji wyborczych do Sejmu i Senatu RP w 2005 r. - AP Opole, Zbiór ks. prałata Czesława Sadłowskiego, Zbiór Jana Bojarczaka - AP Radom, Wojewódzki Komitet Obywatelski „Solidarność” w Zielonej Górze - AP Zielona Góra).

Szczegółowe zasady ewidencjonowania nabytków w postaci elektronicznej zostały wprowadzone w archiwach państwowych w 2014 r. ${ }^{5}$ Wśród an-

4 Trzy archiwa deklarujące posiadanie dokumentacji elektronicznej w zasobie nie podały dat pierwszego przejęcia tej postaci dokumentacji do zasobu.

5 Zarządzeniem Nr 11 Naczelnego Dyrektora Archiwów Państwowych z dnia 4 listopada 2013 r. w sprawie ewidencji zasobu archiwalnego w archiwach państwowych, dostęp online 4.08.2015: http://archiwa.gov.pl/images/stories/Prawoarchiwalne/za- 
kietowanych archiwów dwa nie zarejestrowały swoich dokumentów elektronicznych, jedno zaś użyło do tego celu bazy danych IZA ${ }^{6}$. Pozostałe archiwa wskazały na wykorzystanie narzędzi ewidencyjnych: księga nabytków/ubytków/przesunięć oraz karta zespołu.

Od 2007 r. obowiązują przepisy rozporządzeń wydanych na podstawie delegacji ustawowej z art. 5 ust. 2c w postaci rozporządzenia Ministra Spraw Wewnętrznych i Administracji z dnia 2 listopada 2006 r. w sprawie wymagań technicznych formatów zapisu i informatycznych nośników danych, na których utrwalono materiały archiwalne przekazywane do archiwów państwowych ${ }^{7}$. Rozporządzenie określa wymagania techniczne, jakim powinny odpowiadać formaty zapisu i informatyczne nośniki danych w rozumieniu przepisów ustawy z dnia 17 lutego 2005 r. o informatyzacji działalności podmiotów realizujących zadania publiczne ${ }^{8}$, przekazywane do archiwów państwowych. Rozporządzenie przewiduje konstrukcję paczki archiwalnej z zestawem metadanych w zdefiniowanym formacie. Na pytanie, czy archiwa przejmowały dokumentację elektroniczną zapisaną zgodnie z tymi wymogami, 2 archiwa odpowiedziały twierdząco, 14 nie zetknęło się z taką sytuacją, a jedno archiwum nie udzieliło odpowiedzi. Należy zastrzec, że oba archiwa, które wykazały, że przejmowały dokumentację zgodnie z wyżej przywołanym rozporządzeniem, jednocześnie nie wykazały posiadania dla przejętej dokumentacji metadanych zapisanych zgodnie ze wskazanym w nim schemacie. Oznacza to prawdopodobnie, że rozporządzenie zostało w tym wypadkach zastosowane w zakresie, w jakim odnosi się do przygotowania i przekazania nośnika danych $(\$ 2, \$ 4, \$ 5$ rozporządzenia), a nie w zakresie, w jakim opisuje sposób zapisu danych na nośniku ( $\$ 3$, załącznik do rozporządzenia).

Dokumentacja elektroniczna może być dostarczona do archiwum zarówno na informatycznym nośniku danych, jak i drogą teletransmisji. Wyłącznie z nośników korzystało 14 archiwów, w dwóch przypadkach wykorzystano za-

rz\%C4\%85dzenie\%20nr\%2011\%20z\%204\%2011\%202013.pdf. Zarządzenie weszło w życie z dniem 1 stycznia $2014 \mathrm{r}$.

${ }^{6}$ Baza IZA (Inwentarze Zespołów Archiwalnych) jest użytkowana w archiwach do inwentaryzacji materiałów archiwalnych, jej główną funkcjonalnością jest generowanie i drukowanie na podstawie wprowadzonych danych inwentarzy archiwalnych.

7 Zob. Dz.U. 2006, Nr 206, poz. 1519.

8 Zob. Dz.U. Nr 64, poz. 565 oraz z 2006 r. Nr 12, poz. 65 i Nr 73, poz. 501. 
równo nośniki, jak i teletransmisję, a w jednym przypadku skorzystano wyłącznie z teletransmisji'.

Wśród rodzajów nośników, na których dostarczano dokumentację elektroniczną, archiwa wskazały: dyski optyczne (15), dyskietki magnetyczne (3), taśmy magnetyczne (3) oraz dyski twarde (4) i pamięci flash (1).

Kwestią kluczową przy długotrwałym przechowywaniu dokumentacji elektronicznej jest prowadzenie odpowiedniej polityki bezpieczeństwa danych, uwzględniającej tworzenie kopii zapasowych i migrację danych na nowe nośniki. Jedenaście archiwów tworzy kopie zapasowe, w tym pięć wytworzyło kopie do części posiadanego zasobu dokumentów elektronicznych. Odsetek zasobu dokumentacji elektronicznej objętego polityką tworzenia kopii zapasowych waha się od 15 do $98 \%$ (zob. zał. nr 2, odpowiedź na pytanie nr 18).

Informatyczne nośniki danych, na których przechowywana jest dokumentacja elektroniczna, powinny być okresowo badane pod kątem utrzymywania zdolności do dalszego przechowywania danych bez ryzyka ich utraty. Sześć archiwów prowadzi regularne przeglądy zawartości nośników z danymi cyfrowymi. Wśród archiwów prowadzących przeglądy wskazywano przeglądy coroczne (w tym również przeglądy automatyczne) oraz przeglądy co dwa lata. Jednocześnie archiwa nie przekazały informacji o sposobie dokumentowania procesów przeglądów.

Migrację danych na nowe nośniki (inne niż pierwotne, na których przekazano dane do archiwum) przeprowadzało 9 archiwów, przy czym wszystkie one podjęły decyzję o zachowaniu oryginalnych nośników, na których dostarczono dokumentację. Jednocześnie 3 archiwa przeprowadziły konwersję danych do innych formatów niż oryginalne: we wszystkich przypadkach była to konwersja $\mathrm{z}$ formatu CD Audio do formatu wave. Pięć archiwów napotkało problemy z odczytem danych cyfrowych, a ich najczęstszą przyczyną były: brak stosownego oprogramowania, brak urządzeń oraz degradacja nośnika. W celu odczytania danych przenoszono je na inny nośnik oraz próbowano odczytywać nośnik w innych urządzeniach.

Obecność metadanych przy dokumentacji elektronicznej jest szczególnie istotna, jednak tylko 3 archiwa wskazały, że posiadane przez nie dokumenty opatrzone są metadanymi w formie opisu archiwalnego. Przy tym w pytaniu wskazano, aby nie uwzględniać danych ewidencyjnych wprowadzo-

9 Jedno archiwum wskazało na pozyskanie dokumentacji elektronicznej w procesie digitalizacji oryginalnej dokumentacji użyczonej przez wytwórcę. 
nych do stosownych baz danych (SEZAM, ZoSIA ${ }^{10}$ ) zgodnie z przepisami NDAP oraz metadanych technicznych związanych z działaniem oprogramowania tworzącego dany typ pliku. Jednocześnie na pytanie o opracowywanie dokumentacji elektronicznej 4 archiwa wskazały, że takie prace w odniesieniu do zespołów zawierających dokumentację elektroniczną były prowadzone. Do prac tych wykorzystano bazy danych ZEUS, ZoSIA, IZA ${ }^{11}$. W większym stopniu dokumentacja elektroniczna była poddawana inwentaryzacji - 9 archiwów wskazało na prowadzenie takich prac lub na istnienie ewidencji wykonanej przez wytwórcę dokumentacji. Ewidencja dokumentacji elektronicznej była sporządzana $\mathrm{z}$ wykorzystaniem tych samych narzędzi, które wskazano przy opracowaniu, oraz dodatkowo z wykorzystaniem oprogramowania biurowego (MS Word, MS Excel). Na marginesie można dodać, że żadne archiwum nie przedstawiło potrzeby posiadania wskazówek metodycznych czy katalogu dobrych praktyk dotyczących inwentaryzacji i opracowania dokumentacji elektronicznej, być może dlatego, że prace nad zespołami posiadającymi takie materiały są $\mathrm{w}$ fazie początkowej.

Nie wszystkie archiwa decydują się na udostępnianie dokumentacji elektronicznej (w ankiecie nie pytano o powody nieudostępniania, więc nie wiadomo, czy jest to związane jedynie z postacią dokumentacji, czy stoją za tym inne względy - np. prawne). Siedem archiwów nie udostępnia posiadanej dokumentacji elektronicznej, w tym jedno udostępnia ją tylko swoim pracownikom.

Jak wspomniano wcześniej, od 2014 r. dokumentacja elektroniczna jest, zgodnie z przepisami Naczelnego Dyrektora Archiwów Państwowych, rejestrowana w środkach ewidencyjnych, takich jak księga nabytków/ubytków/ przesunięć międzyzespołowych i karta zespołu. W kolejnym pytaniu ankiety zapytano o ocenę przepisów w tym zakresie. Zdecydowana większość, bo 27 archiwów oceniło przepisy pozytywnie, jedno archiwum nie udzieliło od-

10 Baza SEZAM (System Ewidencji Zasobu Archiwalnego) służy do ewidencji zasobu na poziomie zespołu archiwalnego, ZoSIA (Zintegrowany System Informacji Archiwalnej) umożliwia ewidencję zasobu na poziomie zespołu oraz inwentaryzację i opracowanie materiałów archiwalnych.

11 Baza ZEUS służy do inwentaryzacji fotografii nagrań dźwiękowych i filmów, jest użytkowana w Narodowym Archiwum Cyfrowym. Należy przy tym zaznaczyć, że żadna ze wskazanych baz nie jest przystosowana do opisu dokumentacji elektronicznej, z wyjątkiem systemu ZoSIA, który pozwala opisywać fotografie, nagrania i filmy występujące w postaci cyfrowej. 
powiedzi, a cztery przedstawiły swoje oczekiwania i wątpliwości, formułując konkretne wnioski i propozycje. Wskazano na brak kwalifikacji dla skanów dokumentów ulotnych, a także na konieczność podziału na dokumenty born digital oraz kopie materiałów analogowych w postaci cyfrowej. Podkreślono, że jest to ważny problem, gdyż archiwa coraz częściej przejmują kopie cyfrowe materiałów, których oryginały są przechowywane gdzie indziej. Brak jasnych wytycznych co do sposobu postępowania z tego typu kopiami skutkuje bardzo różną i niejednolitą praktyką, przejawiającą się m.in. w tym, że materiały te, mimo że gromadzone w archiwach, często nie są wykazywane w ewidencji. Ma to poważne skutki dla kompletności systemu informacyjnego archiwów, który powinien obejmować informacje o całości przechowywanych materiałów, zarówno kopii, jak i oryginałów ${ }^{12}$. W odpowiedziach wskazano też, że ze względu na specyfikę dokumentacji elektronicznej należy precyzyjnie wskazać sposób jej przejmowania do archiwów, chociażby przez określenie wymaganych nośników i parametrów opisu. Podobnie jak w postulatach dotyczących sprawozdawczości zauważono, że konieczna jest zmiana w sposobie opisywania „rodzajów” dokumentacji: najpierw należałoby podawać postać (analogowa/elektroniczna), dopiero potem, w ramach tego podziału wyspecyfikować „typy/rodzaje”, tj. dokumentacja: aktowa, kartograficzna, ulotna itd. Obowiązujące obecnie regulacje, przy rejestracji nabytku/ubytku/ przesunięcia przewidują wpisanie dokumentacji elektronicznej jako „rodzaju” dokumentacji, brak natomiast możliwości wpisania „typu”. Nie można więc określić, czy rejestrowana dokumentacja elektroniczna to np. film lub dokument tekstowy, podczas gdy przy opisywaniu dokumentacji tradycyjnej przewidziano taką możliwość.

Brak także jasnych zaleceń co do rejestracji w sytuacji takiej jak nabytek filmu na DVD. Zgodnie z przepisami można go zarejestrować jako dokumentację elektroniczną, jednocześnie jednak przepisy zaliczają taki film do dokumentacji tradycyjnej. Zauważono, że ta niejednolitość zaleceń wprowadza ewidencyjny chaos, tym bardziej że przy opisie zespołu zawierającego taki materiał, po wyborze dokumentacji elektronicznej jako „rodzaju” można jako „typ” dokumentacji wskazać „obrazy ruchome”. Dodatkowo dostrzeżono, że przy wypełnianiu karty zespołu w przypadku dokumentacji elektronicznej

12 W 2007 r. Naczelna Dyrekcja Archiwów Państwowych przedstawiła projekt Wskazówek metodycznych w sprawie postępowania z kopiami w archiwach państwowych, w 2012 r. pojawił się kolejny projekt, jednak do tej pory problem ten nie został uregulowany. 
brakuje możliwości wpisania jako „typu” dokumentacji materiałów ulotnych. Dokumentacja elektroniczna przechowywana $\mathrm{w}$ archiwach państwowych wykazywana jest w sprawozdaniach statystycznych KN-1 od 2009 r. ${ }^{13}$ Przyjęty wówczas sposób określania wielkości zasobu archiwalnego przez wskazanie odrębnej kategorii dokumentów elektronicznych wydaje się nie budzić wątpliwości archiwistów. Na pytanie, czy obowiązujący formularz sprawozdawczy jest wystarczający dla zobrazowania stanu zasobu archiwum, 27 archiwów odpowiedziało twierdząco, a tylko 3, że nie (2 nie udzieliły odpowiedzi na to pytanie). Jednak archiwa, które uznały taki sposób prezentowania wielkości zasobu za wadliwy, wskazały zakres oczekiwanych zmian w formularzu KN-1. Wśród odpowiedzi pojawiło się wskazanie konieczności zasadniczej rewizji sposobu określania wielkości zasobu archiwalnego zawierającego dokumentację elektroniczną. Zaproponowano, aby zamiast osobnej tabeli opisującej dokument elektroniczny (ze specyficznymi kategoriami ze standardu Dublin Core) najpierw podawać „postać” (z rozróżnieniem na analogową i elektroniczną), a w kolejnym etapie, w ramach tego podziału wyspecyfikować „typy” (lub „rodzaje”) dokumentacji, tj. dokumentacja: aktowa, kartograficzna, ulotna itd. Argumentowano, że tylko taki sposób opisu pozwoli na dokładne policzenie i podanie liczby j.a. filmów, map, dokumentacji aktowej itd., bez względu na to, czy zapisana jest ona w postaci tradycyjnej, czy elektronicznej. Podkreślono, że w obecnym sprawozdaniu dla obu postaci dokumentacji podawane są różne określenia „rodzaju” dokumentacji: z jednej strony występuje tradycyjny podział na dokumentację aktową, fotograficzną, kartograficzną, techniczną itd., z drugiej wprowadzono nowy podział na dokumenty: tekstowe, obrazy ruchome i nieruchome, dźwiękowe oraz oprogramowanie i zbiory danych ${ }^{14}$. Obie typologie są rozbieżne (nie można wyodrębnić w dokumentacji elektronicznej dokumentacji kartograficznej i technicznej), co utrudnia zorientowanie się w stanie zasobu ${ }^{15}$. Ponadto zwrócono

13 Rozporządzenie Prezesa Rady Ministrów z dnia 5 maja 2009 r. w sprawie określenia wzorów formularzy sprawozdawczych, objaśnień co do sposobu ich wypełniania oraz wzorów kwestionariuszy i ankiet statystycznych stosowanych w badaniach statystycznych ustalonych w programie badań statystycznych statystyki publicznej na rok 2009, Dz.U. 2009, Nr 85, poz. 717.

${ }_{14}$ Nie ulega przy tym wątpliwości, że zasadne jest opisywanie specyficznych form dokumentów elektronicznych, np. baz danych nowymi i stosownymi określeniami.

15 Zauważyć wypada, że zastosowana w KN-1 typologia dokumentów elektronicznych zgodna jest z typologią wskazaną dla dokumentacji elektronicznej w $₫ 2$ ust. 1 pkt 
uwagę na brak zdefiniowania ,jednostki archiwalnej” w kontekście dokumentu elektronicznego oraz wskazano na konieczność zachowania spójności pomiędzy danymi w sprawozdaniu statystycznym i opisowym. Podniesiono również kwestię traktowania kopii cyfrowych jako części zasobu archiwum, proponując uwzględnienie kopii (skany materiałów analogowych, w tym również w przypadku nieposiadania przez archiwum oryginałów) w zasobie archiwum, jako odrębnego rodzaju materiałów. Zwrócono wreszcie uwagę na potrzebę dodania do sprawozdania $\mathrm{KN}-1$ informacji o liczbie zespołów posiadających dokumentację elektroniczną.

$\mathrm{Z}$ powyższego można wnioskować, że na istniejące dotychczas rozbieżności ewidencyjno-sprawozdawcze, związane z niejednolitymi zaleceniami dotyczącymi zasad wykazywania jednostek archiwalnych/inwentarzowych, występujących głównie przy dokumentacji nieaktowej, w szczególności przy liczeniu fotografii i map, nakładają się problemy związane z dokumentacją elektroniczną. Rychłe uregulowanie tych kwestii wydaje się konieczne, nie tylko dla dobra systemu informacyjnego archiwów, ale także, a być może przede wszystkim, dla celów efektywnego zarządzania zasobem archiwalnym.

$\mathrm{Na}$ pytanie czy archiwum posiada wewnętrzne regulacje własne określające tryb postępowania z dokumentacją elektroniczną stanowiącą zasób archiwum, twierdząco odpowiedziało tylko jedno archiwum, wskazując przy tym, że jest to Regulamin udostępniania.

Wśród innych zagadnień i problemów, które są dostrzegane przez archiwa w związku z dokumentacją elektroniczną, znalazło się wskazanie na odmienność definicji dokumentu elektronicznego użytej w ankiecie od definicji występującej w przepisach prawa oraz na brak wytycznych dotyczących zasad przechowywania dokumentów elektronicznych z naciskiem na wskazanie odpowiednich nośników.

Na podstawie przeprowadzonej ankiety można sformułować następujące wnioski:

- ciągle aktualne są wątpliwości co do zakresu definicji dokumentu elektronicznego i jej zastosowania w praktyce archiwalnej (w tym zwłaszcza w sprawozdawczości),

7 rozporządzenia MSWiA z dnia 30 października 2006 r. w sprawie niezbędnych elementów struktury dokumentów elektronicznych (Dz.U. 2006, Nr 206, poz. 1517). 


\section{Hanna Staszewska, Wojciech Woźniak}

- widoczny jest brak jasności co do zakresu obowiązywania przepisów z 2006 r. dotyczących przekazywania materiałów archiwalnych w postaci cyfrowej do archiwów państwowych,

- zauważalna jest nieznajomość zasad przechowywania dokumentacji elektronicznej (kwestia migracji danych na nowe nośniki, tworzenie kopii zapasowych),

- daje się dostrzec brak jasności co do sposobu opisu i ewidencjonowania dokumentów elektronicznych, mimo że uwagi takie nie zostały w ankiecie sformułowane wprost,

- problemem jest udostępnianie dokumentacji elektronicznej,

- występują problemy techniczne (brak sprzętu do odczytu, brak oprogramowania).

\section{Summary}

Electronic records in state archives - results of a survey conducted in May 2015

The text contains a summary of results of a survey performed in state archives between 6th and 29th May, 2015. The objective of the survey was to gather information on amount of electronic records held currently by state archives, on their state of register, arrangement and description and storage, and to diagnose problems and difficulties met by archivists while working on electronic records. The results of the survey are supposed to serve for analysis of methods and procedures used while dealing with electronic records. 
ZAEĄCZNIK NR I

\section{DOKUMENTACJA ELEKTRONICZNA W ARCHIWACH PAŃSTWOWYCH - ANKIETA}

\section{WPROWADZENIE}

Sanowni Państwo, uprzejmie prosimy o wypełnienie poniższej ankiety,

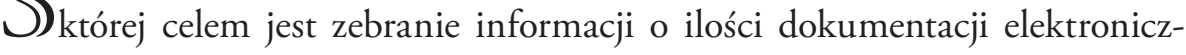
nej przechowywanej obecnie w archiwach państwowych, stanie jej ewidencji, opracowania i przechowywania oraz zdiagnozowanie problemów i trudności napotykanych przez archiwistów w pracy z dokumentacją elektroniczną. Prosimy o szczegółowe wypełnienie ankiety. Autorzy dołożyli wszelkich starań, aby pytania w ankiecie były zrozumiałe i jednoznaczne, a przygotowanie odpowiedzi nie zajmowało więcej czasu niż to konieczne dla celów ankiety.

Na potrzeby ankiety należy przyjąć następujące rozumienie pojęć:

- dokument elektroniczny, dokumentacja w postaci elektronicznej, dokumentacja elektroniczna - zbiór danych zapisany w postaci cyfrowej (tj. w postaci ciągu bitów) na dowolnym informatycznym nośniku danych (np. płycie CD, dysku twardym - HDD, dyskietce elastycznej, taśmie LTO, serwerze, urządzeniu mobilnym itp.), możliwy do odczytania wyłącznie za pośrednictwem odpowiednich urządzeń elektronicznych; może stanowić zbiór od początku istniejący w postaci elektronicznej (naturalny dokument elektroniczny) lub być kopią elektroniczną dowolnej treści zapisanej w postaci innej niż elektroniczna (odwzorowanie cyfrowe); stanowiący zasób archiwum państwowego (jako samodzielny dokument lub jako załącznik do dokumentacji tradycyjnej) i niebędący kopią tradycyjnych materiałów przechowywanych w tym archiwum (np. nie jest produktem prowadzonego w ar- 
chiwum procesu digitalizacji), choć może być kopią dokumentacji tradycyjnej przechowywanej u innego przechowawcy lub wytwórcy dokumentacji. Do uznania zbioru danych za dokument elektroniczny nie jest wymagana żadna forma jego uwierzytelnienia (np. podpis elektroniczny);

- metadane - zestaw usystematyzowanych informacji, logicznie powiązanych z przesyłką, sprawą lub inną dokumentacją, ułatwiających ich wyszukiwanie, kontrolę, zrozumienie i długotrwałe przechowanie oraz zarządzanie ${ }^{1}$.

Proszę udzielić odpowiedzi, w przypadku pytań zamkniętych wpisując znak „x” w polu po lewej stronie wybranej odpowiedzi, a w przypadku pytań otwartych wpisując dane (proszę użyć tyle miejsca, ile potrzeba).

Ankietę proszę wypełnić i odesłać w wersji elektronicznej (plik doc lub .odt) na adres mailowy nac@nac.gov.pl.

\section{Ankieta}

1. Czy archiwum posiada w swoim zasobie dokumentację w postaci elektronicznej?

\begin{tabular}{|l|l|}
\hline & TAK \\
\hline & NIE (proszę przejść do pytania 28) \\
\hline
\end{tabular}

2. Proszę podać datę pierwszego przejęcia dokumentacji elektronicznej do zasobu archiwum.

3. Czy archiwum posiada zespoły/zbiory archiwalne składające się w całości z dokumentacji elektronicznej?

1 Rozporządzenie Prezesa Rady Ministrów z dnia 18 stycznia 2011 r. w sprawie instrukcji kancelaryjnej, jednolitych rzeczowych wykazów akt oraz instrukcji w sprawie organizacji i zakresu działania archiwów zakładowych (Dz.U. 2011, Nr 14, poz. 67). 


\begin{tabular}{|l|l|}
\hline & TAK \\
\hline & NIE (proszę przejść do pytania 5) \\
\hline
\end{tabular}

4. Proszę wskazać zespoły/zbiory archiwalne składające się wyłącznie z dokumentacji elektronicznej.

\begin{tabular}{|c|c|c|c|c|c|c|c|}
\hline Lp. & $\begin{array}{c}\mathrm{Nr} \\
\text { zesp./zb. }\end{array}$ & Nazwa & $\begin{array}{c}\text { Daty } \\
\text { skrajne }^{1}\end{array}$ & $\begin{array}{c}\text { Liczba } \\
\text { doku- } \\
\text { mentów }\end{array}$ & $\begin{array}{c}\text { Liczba } \\
\text { plików }^{2}\end{array}$ & $\begin{array}{c}\text { Rozmiar } \\
\text { w MB }\end{array}$ & Uwagi \\
\hline
\end{tabular}

1 W przypadku kopii cyfrowych dokumentacji tradycyjnej należy podać daty skrajne dokumentacji, a nie daty wykonania kopii. Np. dla kopii cyfrowej dokumentu z 1453 r. datą skrajną będzie rok 1453.

${ }^{2}$ W przypadku niemożliwości podania liczby plików (np. dla zapisów CD-Audio) należy podać w polu uwagi stosowną informację wraz z czasem trwania zapisu w minutach.

5. Czy archiwum posiada zespoły/zbiory archiwalne składające się częściowo z dokumentacji elektronicznej?

\begin{tabular}{|l|l|}
\hline & TAK \\
\hline & NIE (proszę przejść do pytania 7) \\
\hline
\end{tabular}

6. Proszę wskazać zespoły/zbiory archiwalne składające się częściowo z dokumentacji elektronicznej.

\begin{tabular}{|c|c|c|c|c|c|c|c|}
\hline Lp. & $\begin{array}{c}\mathrm{Nr} \\
\text { zesp./ } \\
\text { zb. }\end{array}$ & Nazwa & $\begin{array}{c}\text { Daty } \\
\text { skrajne }^{3}\end{array}$ & $\begin{array}{l}\text { Liczba } \\
\text { doku- } \\
\text { mentów }\end{array}$ & $\begin{array}{l}\text { Liczba } \\
\text { plików }{ }^{4}\end{array}$ & $\begin{array}{c}\text { Rozmiar } \\
\text { w MB }\end{array}$ & Uwagi \\
\hline
\end{tabular}

${ }^{3}$ W przypadku kopii cyfrowych dokumentacji tradycyjnej należy podać daty skrajne dokumentacji, a nie daty wykonania kopii. Np. dla kopii cyfrowej dokumentu z 1453 r. datą skrajną będzie rok 1453.

4 W przypadku niemożliwości podania liczby plików (np. dla zapisów CD-Audio) należy podać w polu uwagi stosowną informację wraz z czasem trwania zapisu w minutach.

7. Czy dokumentacja elektroniczna jest rejestrowana zgodnie z Zarządzeniem Nr 11 Naczelnego Dyrektora Archiwów Państwowych z dnia 4 listopada 2013 r. w sprawie ewidencji zasobu archiwalnego w archiwach państwowych w środkach ewidencyjnych takich jak (można wskazać więcej niż jedną odpowiedź): 


\begin{tabular}{|l|l|}
\hline & Księga nabytków \\
\hline & Księga ubytków \\
\hline & Księga przesunięć międzyzespołowych \\
\hline & Karta zespołu \\
\hline & Inne (jakie?) ................................................ \\
\hline & Nie jest rejestrowana \\
\hline
\end{tabular}

8. Czy przejęta dokumentacja elektroniczna zapisana była zgodnie z przepisami rozporządzenia MSWiA z dnia 2 listopada 2006 r. w sprawie wymagań technicznych formatów zapisu i informatycznych nośników danych, na których utrwalono materiały archiwalne przekazywane do archiwów państwowych?

\begin{tabular}{|l|l|}
\hline & TAK \\
\hline & NIE \\
\hline
\end{tabular}

9. Archiwum przejęło dokumentację elektroniczną za pośrednictwem (można wskazać więcej niż jedną odpowiedź):

\begin{tabular}{|l|l|}
\hline & Teletransmisji \\
\hline & Na nośnikach danych \\
\hline $\begin{array}{l}\text { Transmisji z dostarczonych nośników (nośniki } \\
\text { zostały zwrócone) }\end{array}$ \\
\hline
\end{tabular}

10. Na jakich (lub z jakich) nośnikach archiwum przejęło dokumentację elektroniczną (można wskazać więcej niż jedną odpowiedź)?

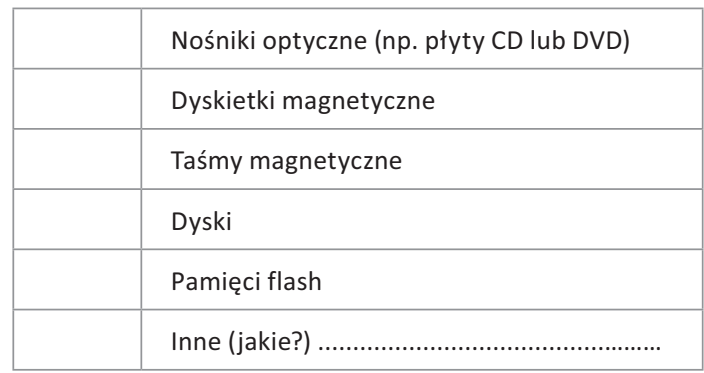


11. Czy dokumentacja elektroniczna była/jest migrowana na kolejne nośniki?

\begin{tabular}{|l|l|}
\hline & TAK \\
\hline & NIE (proszę przejść do pytania 13) \\
\hline
\end{tabular}

12. Czy oryginalne nośniki są przechowywane nadal?

\begin{tabular}{|l|l|}
\hline & TAK \\
\hline & NIE \\
\hline
\end{tabular}

13. Czy dokumentacja elektroniczna była/jest konwertowana do nowszych/ współczesnych formatów danych?

\begin{tabular}{|l|l|}
\hline & TAK \\
\hline & NIE (proszę przejść do pytania 15) \\
\hline
\end{tabular}

14. Proszę podać, z jakich formatów do jakich przeprowadzono konwersję: format pierwotny:

format po konwersji:

15. Czy występowały/występują problemy z odczytem danych cyfrowych?

\begin{tabular}{|l|l|}
\hline & TAK \\
\hline & NIE (proszę przejść do pytania 18) \\
\hline
\end{tabular}

16. Proszę podać zdiagnozowane przyczyny problemów z odczytem danych cyfrowych (można wskazać więcej niż jedną odpowiedź)

\begin{tabular}{|c|}
\hline Brak odpowiedniego oprogramowania do odczytu \\
\hline Brak odpowiednich urządzeń do odczytu nośnika \\
\hline Degradacja nośnika \\
\hline Inne (jakie?) ...... \\
\hline
\end{tabular}




\section{Hanna Staszewska, Wojciech Woźniak}

17. Proszę podać, czy podjęto działania w celu odczytania danych (jakie?):

18. Czy dokumentacja elektroniczna posiada kopię zapasową?

\begin{tabular}{|c|}
\hline TAK \\
\hline NIE \\
\hline $\begin{array}{l}\text { Częściowo (proszę podać szacunkowy pro- } \\
\text { cent dokumentacji posiadającej kopie zapa- } \\
\text { sowe) }\end{array}$ \\
\hline
\end{tabular}

19. Czy prowadzi się regularne przeglądy zawartości nośników z danymi cyfrowymi?

\begin{tabular}{|l|l|}
\hline & TAK \\
\hline & NIE (proszę przejść do pytania 21) \\
\hline
\end{tabular}

20. Proszę scharakteryzować zastosowaną metodę (proszę np. wskazać, jak często prowadzi się przeglądy, jaka dokumentacja wówczas powstaje, jakie działania podejmuje się w efekcie stwierdzonego stanu)

21. Czy dokumentacja elektroniczna posiada metadane?

\begin{tabular}{|l|l|}
\hline & TAK \\
\hline & NIE (proszę przejść do pytania 23) \\
\hline
\end{tabular}

22. Proszę podać standard zapisu metadanych (np. PREMIS, struktura metadanych wynikająca z rozporządzenia MSWiA z dnia 2 listopada 2006 r.

2 Proszę nie uwzględniać danych ewidencyjnych wprowadzonych do stosownych baz danych zgodnie z przepisami NDAP oraz metadanych technicznych związanych z działaniem oprogramowania tworzącego dany typ pliku. 
w sprawie wymagań technicznych formatów zapisu i informatycznych nośników danych, na których utrwalono materiały archiwalne przekazywane do archiwów państwowych) lub jeśli nie zastosowano standardu, proszę wymienić elementy metadanych oraz sposób ich zapisu (np. format, zastosowana baza danych itp.).

23. Czy dokumentacja elektroniczna była/jest poddawana opracowywaniu archiwalnemu:

\begin{tabular}{|l|l|}
\hline & TAK \\
\hline & NIE (proszę przejść do pytania 25) \\
\hline
\end{tabular}

24. Jeśli tak, proszę wskazać narzędzia wykorzystane do sporządzenia inwentarza.

25. Czy dokumentacja elektroniczna była/jest inwentaryzowana?

\begin{tabular}{|l|l|}
\hline & TAK \\
\hline & NIE (proszę przejść do pytania 27) \\
\hline
\end{tabular}

26. Proszę wskazać narzędzia wykorzystane do sporządzenia spisów.

27. Czy dokumentacja elektroniczna jest udostępniana użytkownikom/pracownikom archiwum?

\begin{tabular}{|l|l|}
\hline & TAK \\
\hline & NIE \\
\hline
\end{tabular}

28. Czy obecnie obowiązujące przepisy o ewidencji wyczerpują potrzeby archiwum w zakresie ewidencji dokumentacji elektronicznej? 


\begin{tabular}{|l|l|}
\hline & TAK, nie wymagają zmian ani uzupełnień (proszę przejść do pytania 30) \\
\hline & NIE, wymagają zmian i uzupełnień \\
\hline
\end{tabular}

29. Proszę wskazać oczekiwane zmiany i uzupełnienia dotyczące dokumentacji elektronicznej w obecnie obowiązujących przepisach o ewidencji:

30. Czy obecnie obowiązujące formularze sprawozdawcze KN-1 wyczerpują potrzeby archiwum w zakresie dokumentacji elektronicznej?

\begin{tabular}{|l|l|}
\hline & TAK, nie wymagają zmian ani uzupełnień (proszę przejść do pytania 32) \\
\hline & NIE, wymagają zmian i uzupełnień \\
\hline
\end{tabular}

31. Proszę rozwinąć poprzez wskazanie oczekiwanych zmian i uzupełnień

32. Czy archiwum posiada wewnętrzne regulacje własne określające tryb postępowania z dokumentacją elektroniczną stanowiącą zasób archiwum?

\begin{tabular}{|l|l|}
\hline & TAK \\
\hline & NIE (proszę przejść do pytania 34) \\
\hline
\end{tabular}

33. Proszę wskazać te regulacje.

34. Proszę wpisać inne uwagi, spostrzeżenia lub informacje, istotne dla powyższej tematyki, a nieujęte w pytaniach. 
ZAŁĄCZNIK NR 2

DOKUMENTACJA ELEKTRONICZNA W ARCHIWACH PAŃSTWOWYCH - ZESTAWIENIE ZBIORCZE WYNIKÓW ANKIETY PRZEPROWADZONEJ W MAJU 2015 R. W ARCHIWACH PAŃSTWOWYCH ${ }^{1}$

1. Czy archiwum posiada w swoim zasobie dokumentację w postaci elektronicznej?

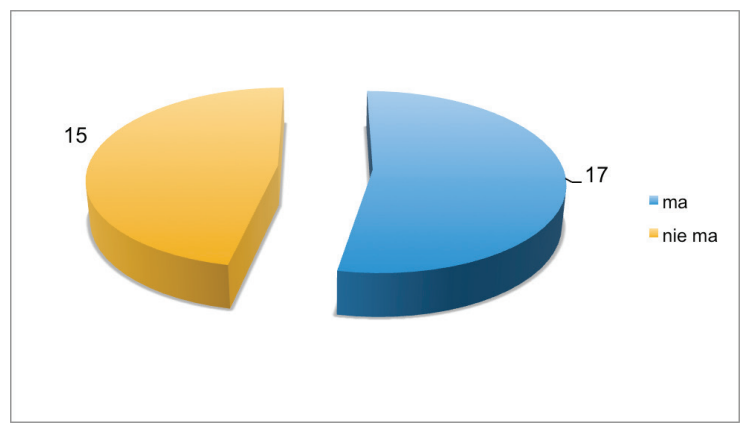

1 Odpowiedzi na pytania 4 i 6 znajdują się na końcu dokumentu. 


\section{Hanna Staszewska, Wojciech Woźniak}

2. Proszę podać datę pierwszego przejęcia dokumentacji elektronicznej do zasobu archiwum ${ }^{2}$.

\begin{tabular}{|c|c|}
\hline \hline Rok przejęcia & Liczba archiwów \\
\hline 2006 & 2 \\
\hline 2007 & 2 \\
\hline 2009 & 1 \\
\hline 2010 & 1 \\
\hline 2011 & 1 \\
\hline 2012 & 2 \\
\hline 2013 & 2 \\
\hline 2014 & 1 \\
\hline $2015^{*}$ & 2 \\
\hline
\end{tabular}

* Obejmuje okres do chwili przeprowadzenia ankiety, tj. do maja 2015 r.

3. Czy archiwum posiada zespoły/zbiory archiwalne składające się w całości z dokumentacji elektronicznej?

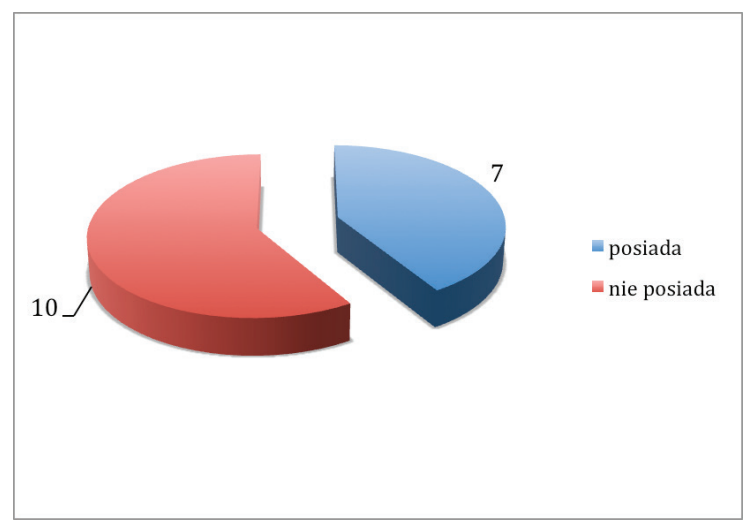

2 Wielkości parametrów w pytaniach 2-27 podawane są w odniesieniu do liczby archiwów deklarujących posiadanie dokumentacji elektronicznej w zasobie, tj. do liczby 17. 
5. Czy archiwum posiada zespoły/zbiory archiwalne składające się częściowo $\mathrm{z}$ dokumentacji elektronicznej?

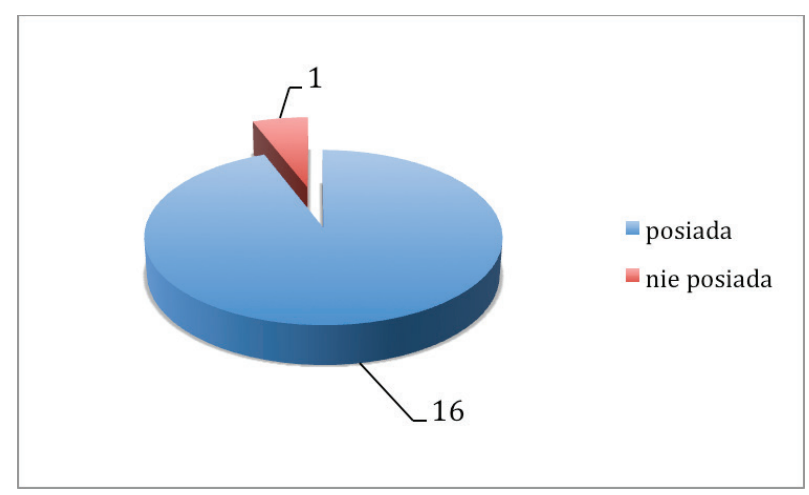

7. Czy dokumentacja elektroniczna jest rejestrowana zgodnie z Zarządzeniem Nr 11 Naczelnego Dyrektora Archiwów Państwowych z dnia 4 listopada 2013 r. w sprawie ewidencji zasobu archiwalnego w archiwach państwowych w środkach ewidencyjnych takich jak (można wskazać więcej niż jedną odpowiedź):

\begin{tabular}{|l|c|}
\hline \hline \multicolumn{1}{|c|}{ Środek ewidencyjny } & Liczba archiwów \\
\hline \hline Księga nabytków & 13 \\
\hline Księga ubytków & 1 \\
\hline Księga przesunięć międzyzespołowych & 1 \\
\hline Karta zespołu & 14 \\
\hline Inne (jakie?) IZA & 1 \\
\hline Nie jest rejestrowana & 1 \\
\hline \hline
\end{tabular}




\section{Hanna Staszewska, Wojciech Woźniak}

8. Czy przejęta dokumentacja elektroniczna zapisana była zgodnie z przepisami rozporządzenia MSWiA z dnia 2 listopada 2006 r. w sprawie wymagań technicznych formatów zapisu i informatycznych nośników danych, na których utrwalono materiały archiwalne przekazywane do archiwów państwowych?

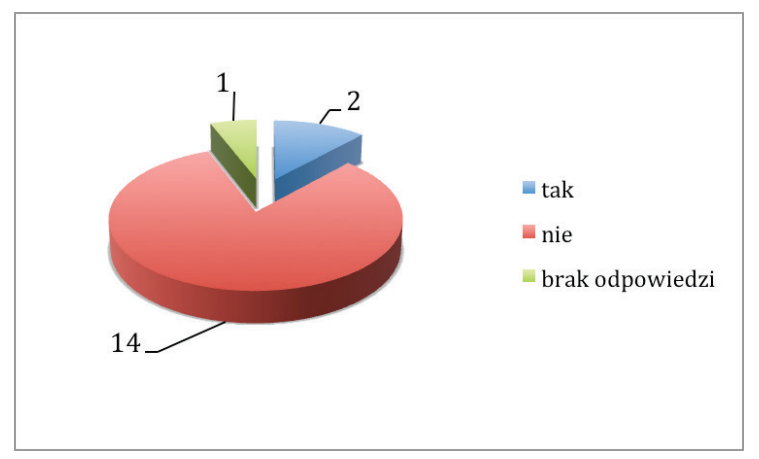

9. Archiwum przejęło dokumentację elektroniczną za pośrednictwem (można wskazać więcej niż jedną odpowiedź):

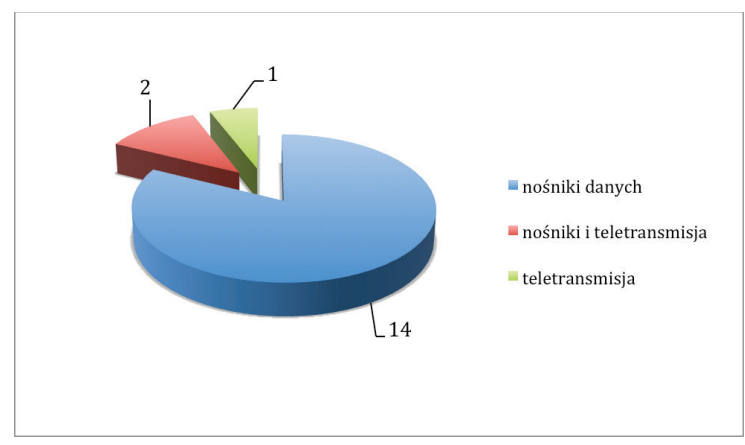


10. Na jakich (lub z jakich) nośnikach archiwum przejęło dokumentację elektroniczną (można wskazać więcej niż jedną odpowiedź)?

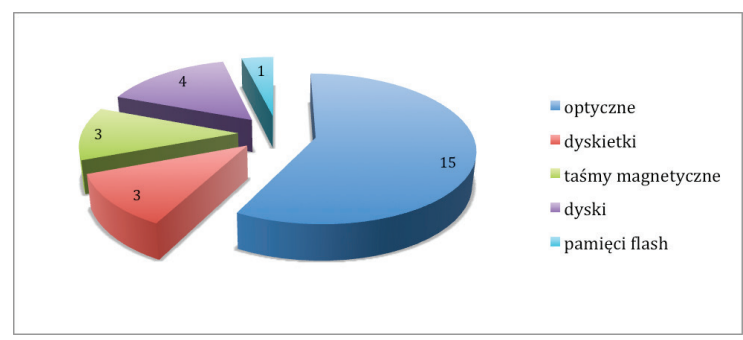

11. Czy dokumentacja elektroniczna była/jest migrowana na kolejne nośniki?

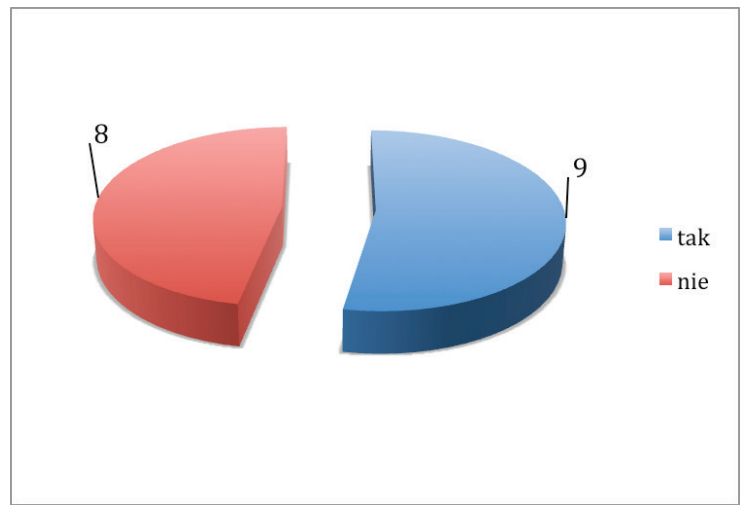

12. Czy oryginalne nośniki są przechowywane nadal?

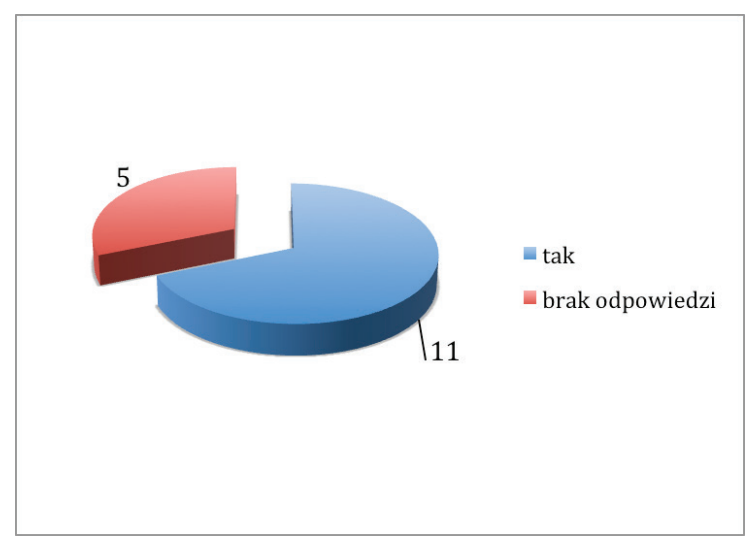




\section{Hanna Staszewska, Wojciech Woźniak}

13. Czy dokumentacja elektroniczna była/jest konwertowana do nowszych/ współczesnych formatów danych?

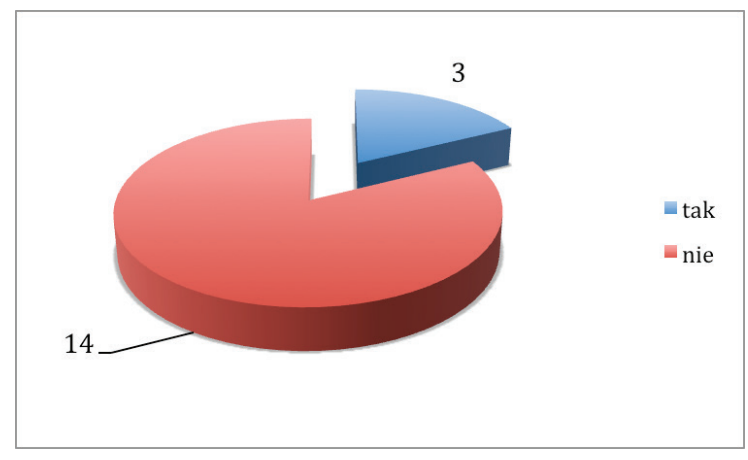

14. Proszę podać, z jakich formatów do jakich przeprowadzono konwersję: 2 archiwa format pierwotny: CDAudio format po konwersji: wave

15. Czy występowały/występują problemy z odczytem danych cyfrowych?

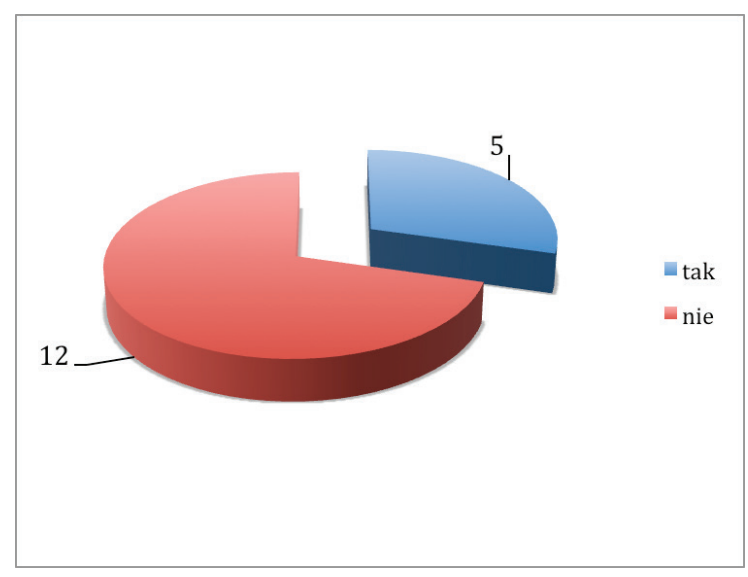


16. Proszę podać zdiagnozowane przyczyny problemów z odczytem danych cyfrowych (można wskazać więcej niż jedną odpowiedź).

\begin{tabular}{|l|c|}
\hline \hline \multicolumn{1}{|c|}{ Przyczyna } & Liczba wystąpień \\
\hline \hline Brak odpowiedniego oprogramowania do odczytu & 2 \\
\hline Brak odpowiednich urządzeń do odczytu nośnika & 2 \\
\hline Degradacja nośnika & 5 \\
\hline Inne (jakie?) & 0 \\
\hline \hline
\end{tabular}

17. Proszę podać, czy podjęto działania w celu odczytania danych (jakie?):

- zgłoszono problem komórce IT, która bada możliwości rozwiązania problemu;

- przeprowadzono próbę zgrania na nowy nośnik i przegrania na serwer;

- przeprowadzono próby odzyskania danych poprzez odczyt na innych urządzeniach/przy pomocy innego oprogramowania.

18. Czy dokumentacja elektroniczna posiada kopię zapasową?

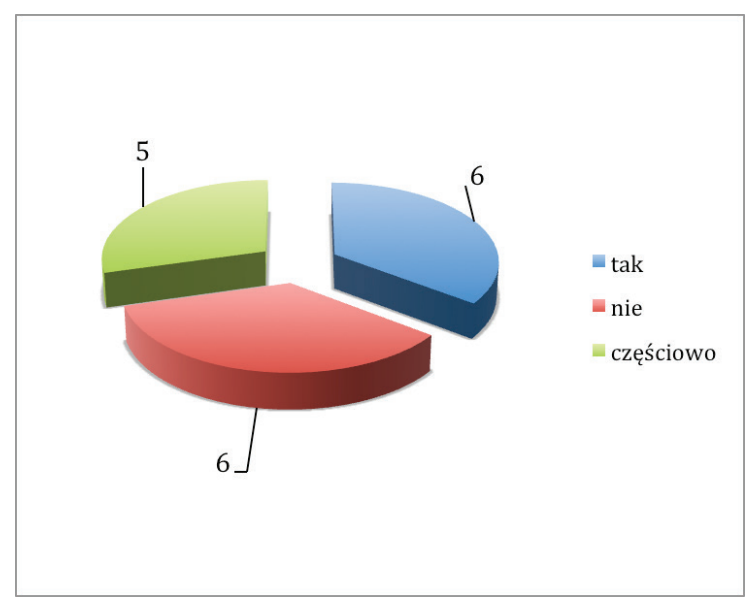

Częsciowo: od 15 do 98\%. 
180 Hanna Staszewska, Wojciech Woźniak

19. Czy prowadzi się regularne przeglądy zawartości nośników z danymi cyfrowymi?

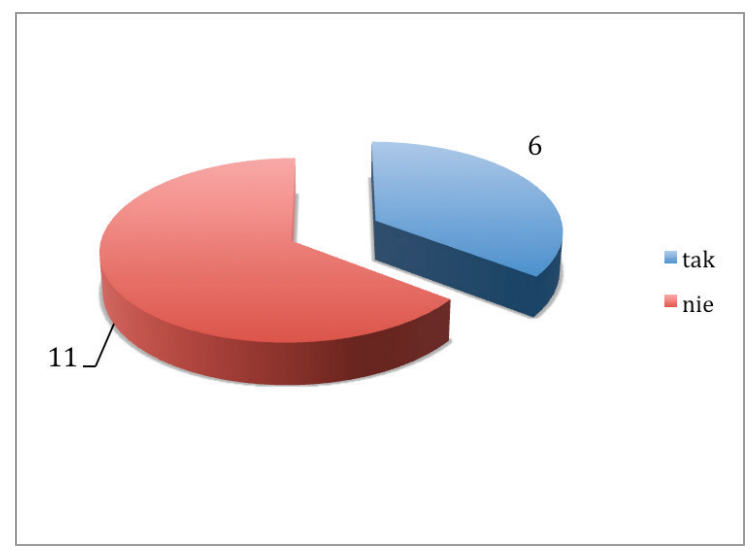

20. Proszę scharakteryzować zastosowaną metodę (proszę np. wskazać, jak często prowadzi się przeglądy, jaka dokumentacja wówczas powstaje, jakie działania podejmuje się w efekcie stwierdzonego stanu)

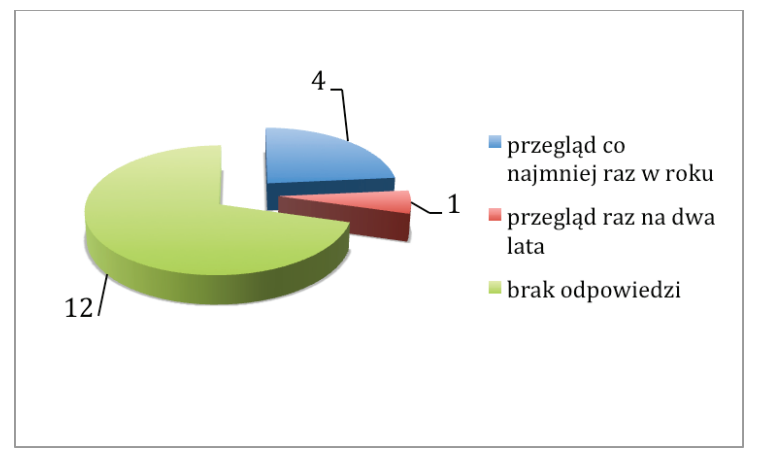


21. Czy dokumentacja elektroniczna posiada metadane?

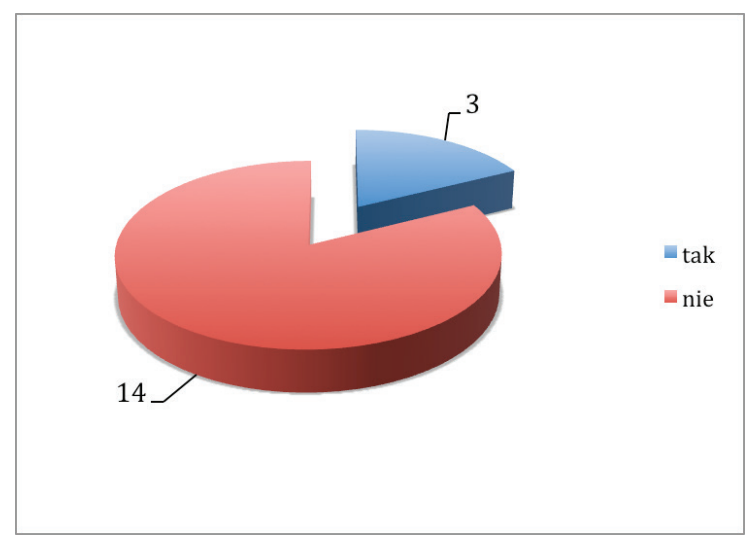

22. Proszę podać standard zapisu metadanych.

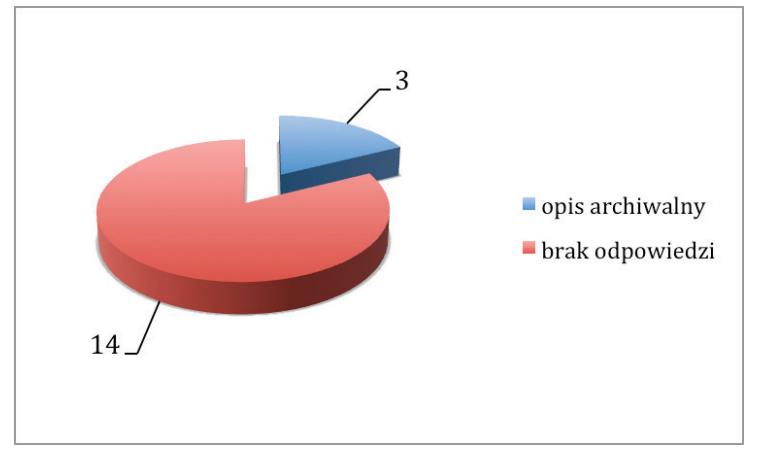


182 Hanna Staszewska, Wojciech Woźniak

23. Czy dokumentacja elektroniczna była/jest poddawana opracowywaniu archiwalnemu?

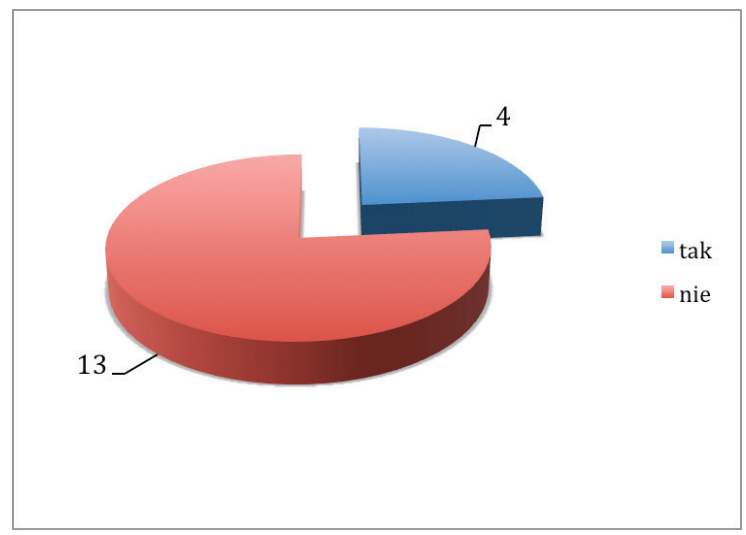

24. Jeśli tak, proszę wskazać narzędzia wykorzystane do sporządzenia inwentarza.

- ZoSIA, IZA, ZEUS

25. Czy dokumentacja elektroniczna była/jest inwentaryzowana?

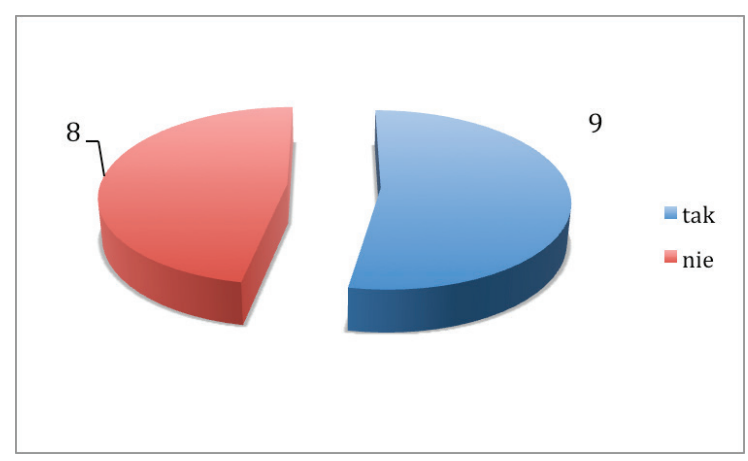


26. Proszę wskazać narzędzia wykorzystane do sporządzenia spisów:

- ZEUS, ZoSIA, MS EXCEL, IZA, MS WORD

27. Czy dokumentacja elektroniczna jest udostępniana użytkownikom/pracownikom archiwum?

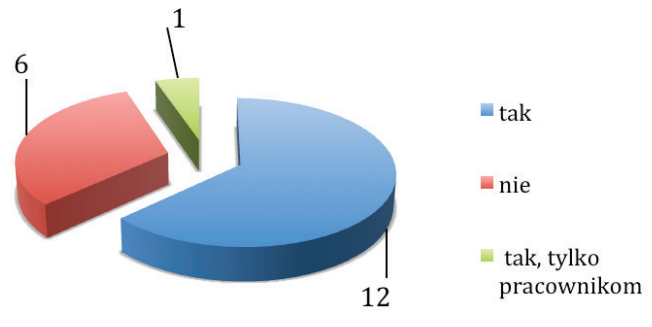

28. Czy obecnie obowiązujące przepisy o ewidencji wyczerpują potrzeby archiwum w zakresie ewidencji dokumentacji elektronicznej?
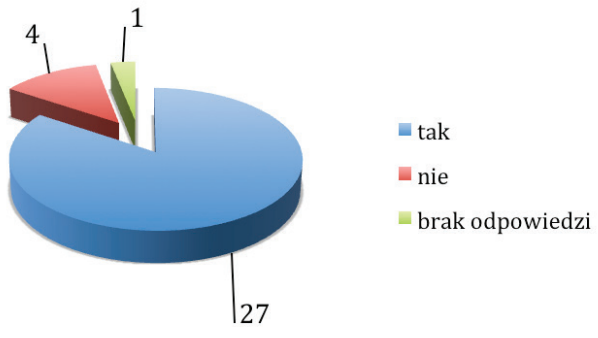
29. Proszę wskazać oczekiwane zmiany i uzupełnienia dotyczące dokumentacji elektronicznej w obecnie obowiązujących przepisów o ewidencji:

- brak kwalifikacji dla skanów dokumentów ulotnych. Konieczny podział na dokumenty born digital oraz kopie materiałów analogowych w postaci cyfrowej;

- należy określić zasady szczegółowego ewidencjonowania dokumentacji elektronicznej (plików, dokumentów) w ramach zespołów archiwalnych: np. za pomocą jakich elementów musi być opisana zawartość (treść) plików dokumentacji elektronicznej;

- w przepisach należy precyzyjnie określić sposób jej przejmowania do archiwów, chociażby określić wymagane nośniki i paramentry opisu;

- konieczna jest zmiana w zapisie rodzajów dokumentacji: najpierw należałoby podawać postać (analogiczna/elektroniczna), a potem, w ramach tego podziału, wyspecyfikowanie typów/rodzajów: np. aktowa, kartograficzna, ulotna;

- rejestracja nabytku/ubytku/przesunięcia przewiduje wpisanie dokumentacji elektronicznej jako rodzaju dokumentacji, brak natomiast możliwości wpisania typu (czyli np. film lub dokumenty tekstowe) przy dokumentacji tradycyjnej taka opcja istnieje;

- brak jasnych zaleceń co do rejestracji nabytku filmu na DVD: można go zapisać jako dokumentację elektroniczną, jednocześnie przepisy zaliczają taki film do dokumentacji tradycyjnej (zob. Zarządzenie nr 11 NDAP z 4 listopada 2013 r. w sprawie ewidencji zasobu archiwalnego w archiwach państwowych i zał. do tegoż (Instrukcję): $\$ 1 \mathrm{pkt}$ 4 ust. 7). Ta niejednolitość zaleceń wprowadza bałagan ewidencyjny, tym bardziej że przy opisie zespołu, po wyborze dokumentacji elektronicznej jako rodzaju dokumentacji, można jako typ dokumentacji wskazać filmy jako obrazy ruchome;

- przy wypełnianiu karty zespołu w przypadku dokumentacji elektronicznej brakuje możliwości wpisania jako typu dokumentacji materiałów ulotnych. 
30. Czy obecnie obowiązujące formularze sprawozdawcze KN-1 wyczerpują potrzeby archiwum w zakresie dokumentacji elektronicznej?

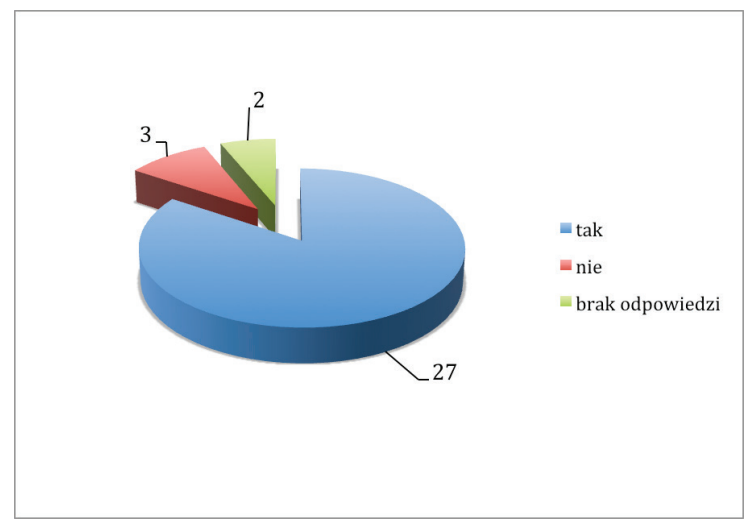

31. Proszę rozwinąć poprzez wskazanie oczekiwanych zmian i uzupełnień:

- uwzględnienie kopii (skany materiałów analogowych, w tym również w przypadku nieposiadania przez archiwum oryginałów) w zasobie archiwum, jako odrębnego rodzaju materiałów;

- konieczna jest zmiana w zapisie rodzajów dokumentacji: najpierw należałoby podawać postać (analogowa/elektroniczna), a potem, w ramach tego podziału, wyspecyfikowanie typów/rodzajów: np. aktowa, kartograficzna, ulotna. Tylko taki zapis pozwoli na dokładne policzenie i podanie ilości j.a. filmów, map, dokumentacji aktowej, bez względu na postać dokumentacji. W obecnym sprawozdaniu osobno podaje się te same rodzaje dokumentacji, czyli filmy, mapy, fotografie (osobno liczy się np. fotografie tradycyjne i osobno cyfrowe), co utrudnia zorientowanie się w stanie zasobu. Nasuwa się tu pytanie: czy dokument elektroniczny to jednostka archiwalna? Jeśli tak, to j.a. dokumentacji tradycyjnej i elektronicznej powinny być liczone łącznie jako cały zasób. Należy też zadbać o spójność danych występujących w formularzu KN-1 oraz odpowiednich tabelach w sprawozdaniu opisowym;

- o dane o ilości zespołów posiadających dokumentację elektroniczną (chociaż niekoniecznie - gdy na razie nie ma lub niewielkie są rozmiary takiej dokumentacji w zasobach archiwów). 
32. Czy archiwum posiada wewnętrzne regulacje własne określające tryb postępowania z dokumentacją elektroniczną stanowiącą zasób archiwum?

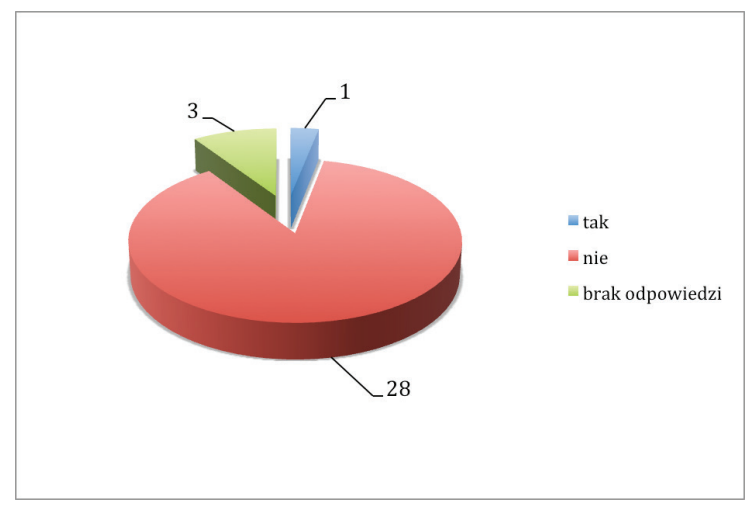

33. Proszę wskazać te regulacje.

- Regulamin udostępniania

34. Proszę wpisać inne uwagi, spostrzeżenia lub informacje, istotne dla powyższej tematyki, a nieujęte w pytaniach.

- brak ogólnych wytycznych gdzie, na jakich nośnikach należy przechowywać dokumentację elektroniczną;

- na etapie gdy Archiwum nie przejmuje dokumentacji elektronicznej, nie jesteśmy w stanie stwierdzić, czy obowiązujące przepisy o ewidencji, jak i formularz sprawozdawczy KN-1 wyczerpują potrzeby archiwum w zakresie dokumentacji elektronicznej. Dopiero konfrontacja przepisów z praktyką nakreśli ewentualne potrzeby uzupełnień i zmian przepisów;

- AP Koszalin prowadzi obecnie prace nad wdrożeniem systemu do Elektronicznego Zarządzania Dokumentacją przy współpracy z Podlaskim Urządem Wojewódzkim w Białymstoku;

- wyjaśnienia wymaga kwestia definicji dokumentu elektronicznego użytej w ankiecie, która jest inna niż w rozumieniu przepisów prawa o dokumencie elektronicznym. Generuje to problemy interpretacyjne w przypadku np. wypełniania formularza KN-1. 


\begin{tabular}{|c|c|c|c|c|c|c|c|c|}
\hline 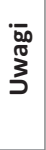 & $\frac{0}{\frac{0}{0}} \stackrel{\substack{0 \\
0}}{\frac{0}{2}}$ & & $\begin{array}{l}\bar{\pi} \\
\frac{\pi}{50} \\
\frac{00}{\overline{0}} \\
\frac{5}{0} \\
8\end{array}$ & & & $\begin{array}{l}\bar{\pi} \\
\frac{\pi}{00} \\
.00 \\
\frac{0}{0} \\
\frac{5}{0} \\
8\end{array}$ & 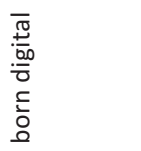 & \\
\hline 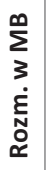 & 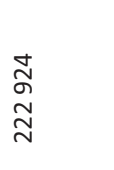 & $\underset{\vec{b}}{\stackrel{\nabla}{\forall}}$ & 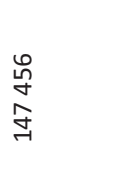 & $\begin{array}{l}0 \\
\tilde{n}\end{array}$ & 옥 & $\underset{ }{\stackrel{-}{ }}$ & 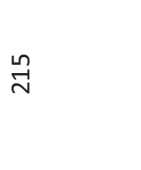 & 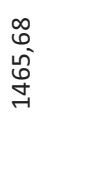 \\
\hline 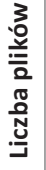 & $\begin{array}{l}\infty \\
\stackrel{-}{-} \\
\text { ○ }\end{array}$ & $\stackrel{m}{\stackrel{n}{n}}$ & $\stackrel{\text { 욱 }}{+}$ & ำ & 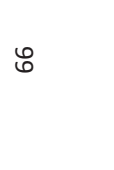 & $\stackrel{\stackrel{\leftrightarrow}{N}}{N}$ & ถิ & $\stackrel{m}{\infty}$ \\
\hline 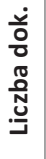 & 1 & $\stackrel{n}{n}$ & $\stackrel{\text { O̊ }}{\underset{\sim}{+}}$ & 요 & $\mathscr{6}$ & $\stackrel{\stackrel{\leftrightarrow}{N}}{N}$ & in & 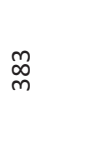 \\
\hline 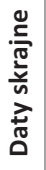 & 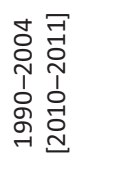 & 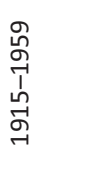 & 옴 & $\begin{array}{l}\text { ले } \\
\text { Oे } \\
\stackrel{1}{1} \\
\text { ने } \\
\text { ने }\end{array}$ & 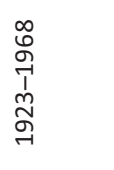 & 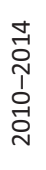 & 옴 & 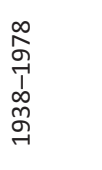 \\
\hline 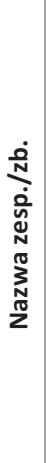 & 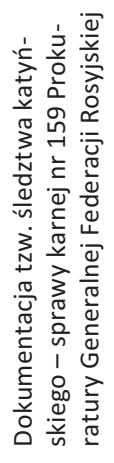 & 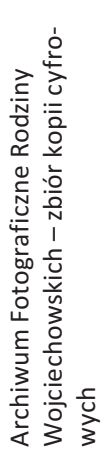 & 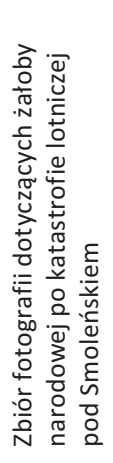 & 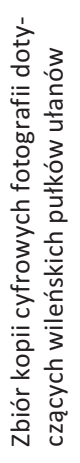 & 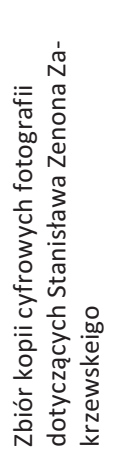 & 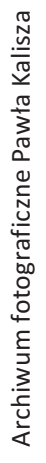 & 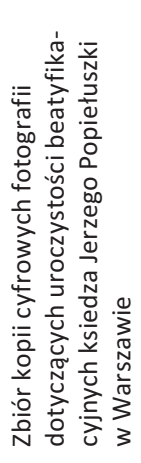 & 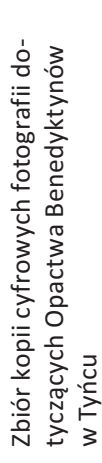 \\
\hline $\begin{array}{l}\frac{D}{N} \\
\frac{D}{n} \\
\stackrel{N}{N} \\
\frac{1}{z}\end{array}$ & $\stackrel{\stackrel{n}{N}}{\stackrel{n}{N}}$ & $\underset{n}{\stackrel{\Omega}{n}}$ & $\frac{\vec{N}}{m}$ & $\frac{n}{n}$ & $\frac{\mathbb{N}}{\stackrel{m}{m}}$ & $\frac{n}{\frac{n}{m}}$ & $\frac{\stackrel{2}{m}}{m}$ & $\frac{\infty}{\frac{\infty}{m}}$ \\
\hline 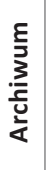 & 这 & $\frac{u}{z}$ & U⿺ & 这 & $\frac{u}{z}$ & $\frac{\pi}{z}$ & u & ù \\
\hline$\stackrel{\dot{3}}{ }$ & $\neg$ & $N$ & $m$ & $\nabla$ & เn & 6 & $r$ & $\infty$ \\
\hline
\end{tabular}




\begin{tabular}{|c|c|c|c|c|c|c|c|}
\hline 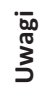 & & & & & & & \\
\hline $\begin{array}{l}\infty \\
\sum_{3} \\
3 \\
\dot{\Sigma} \\
0 \\
\propto\end{array}$ & 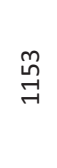 & 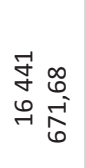 & $\stackrel{n}{n}$ & 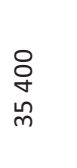 & 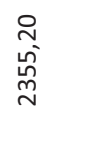 & $\begin{array}{l}0 \\
ٌ \\
\circ \\
\circ \\
-1\end{array}$ & 吕 \\
\hline 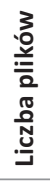 & $\sim$ & 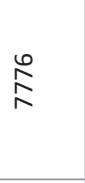 & $\hat{\vec{\sigma}}$ & 1 & 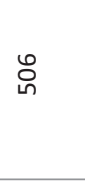 & 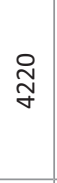 & 1 \\
\hline 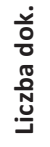 & ' & ' & ' & $\vec{G}$ & 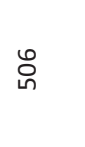 & 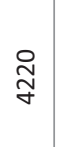 & $\sim$ \\
\hline 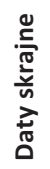 & $\begin{array}{l}\infty \\
\stackrel{\infty}{\rightarrow} \\
\end{array}$ & 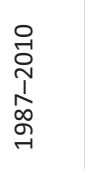 & ঃ̊̀ & 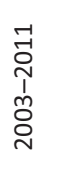 & 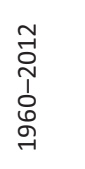 & 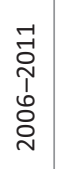 & 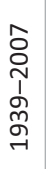 \\
\hline 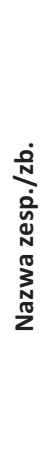 & 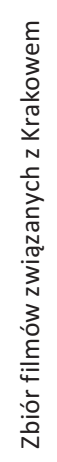 & 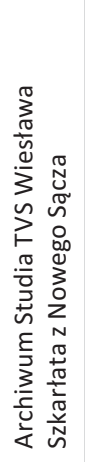 & 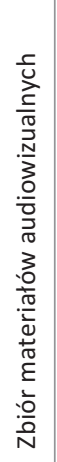 & 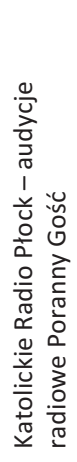 & 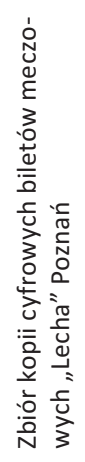 & 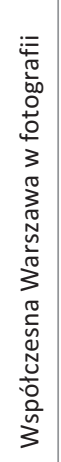 & 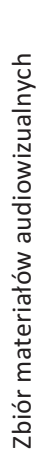 \\
\hline $\begin{array}{l}\frac{\dot{N}}{N} \\
\frac{\dot{d}}{y} \\
\frac{N}{2}\end{array}$ & 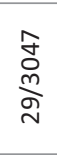 & 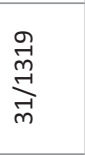 & $\underset{\sim}{\stackrel{D}{\sim}}$ & $\begin{array}{l}\text { f } \\
\text { D } \\
\text { o }\end{array}$ & 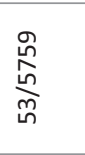 & $\underset{\substack{n \\
\stackrel{N}{N}}}{\stackrel{-}{N}}$ & $\underset{\stackrel{n}{g}}{\stackrel{f}{ }}$ \\
\hline 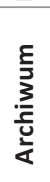 & 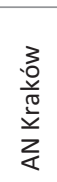 & $\begin{array}{l}\frac{3}{0} \\
\frac{0}{\sqrt{0}} \\
\frac{2}{2} \\
\frac{2}{4}\end{array}$ & $\begin{array}{l}\frac{5}{3} \\
\text { N } \\
\frac{N}{0} \\
\frac{1}{<}\end{array}$ & $\begin{array}{l}\text { ․ㅡㅁ } \\
\frac{0}{0} \\
\frac{0}{\alpha}\end{array}$ & 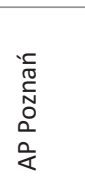 & 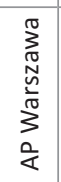 & 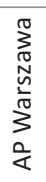 \\
\hline$\dot{9}$ & $\sigma$ & 요 & $\exists$ & テ & $\stackrel{m}{\sim}$ & $\vec{J}$ & 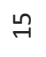 \\
\hline
\end{tabular}




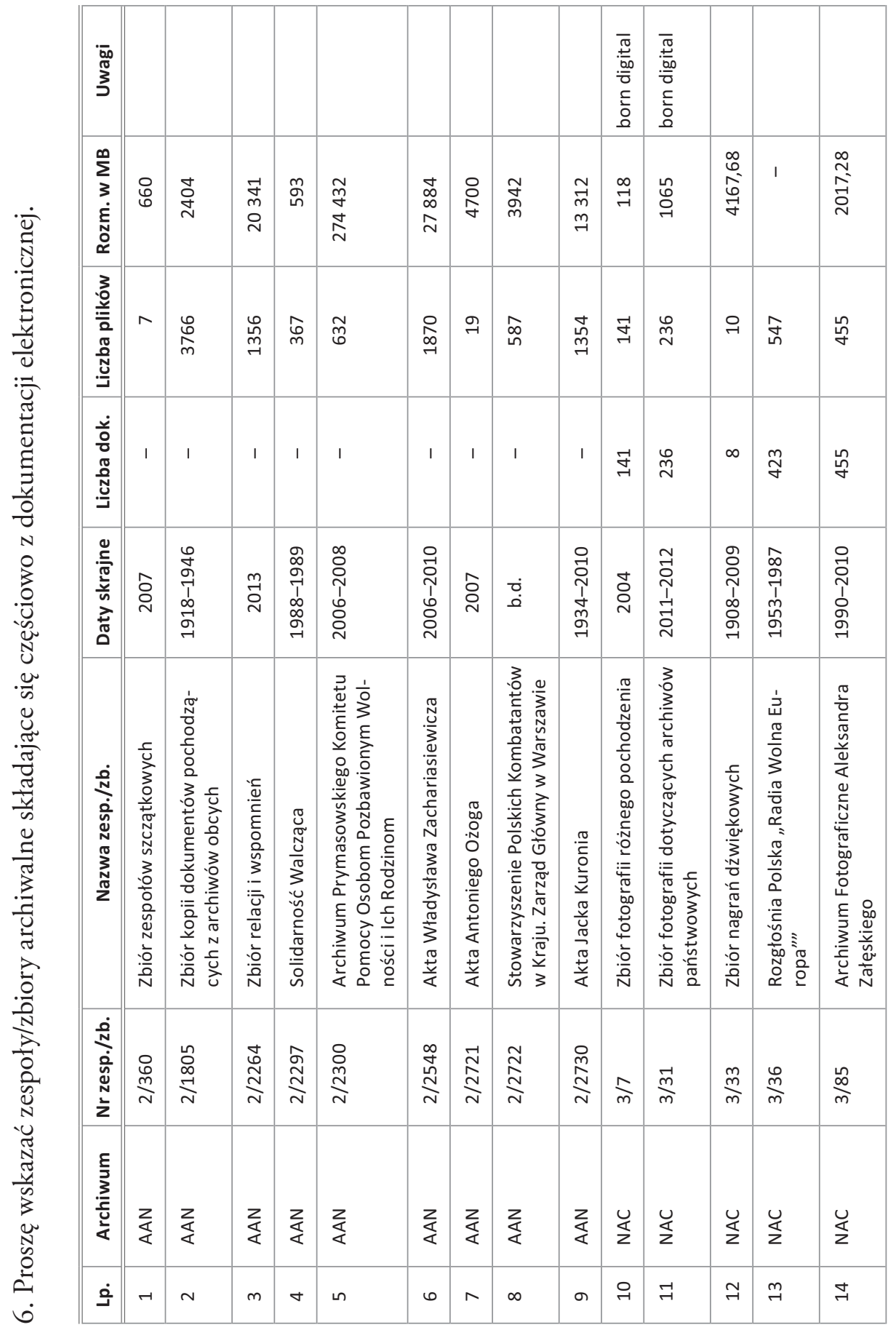




\begin{tabular}{|c|c|c|c|c|c|c|c|c|c|c|c|c|c|}
\hline 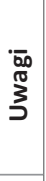 & & & $\frac{\sum_{0}^{0}}{\frac{0}{0}}$ & 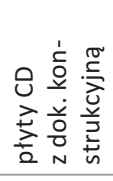 & 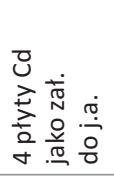 & & & & & & & 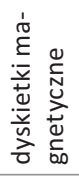 & 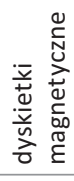 \\
\hline 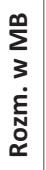 & $\underset{f}{\sigma}$ & $\stackrel{\operatorname{Ln}}{\stackrel{\sim}{\sim}}$ & $\begin{array}{l}\underset{G}{-1} \\
\underset{-1}{1}\end{array}$ & $\underset{-}{\stackrel{8}{2}}$ & 엄 & $\underset{\text { ㄱ. }}{\stackrel{\text { }}{2}}$ & 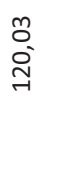 & ০ & $\begin{array}{l}\stackrel{+}{0} \\
\stackrel{\omega}{N}\end{array}$ & $\underset{\sim}{\stackrel{-}{\sim}}$ & $\begin{array}{l}\stackrel{d}{\sim} \\
\stackrel{\sim}{N} \\
\underset{N}{N}\end{array}$ & 1 & 1 \\
\hline 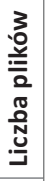 & $\sim$ & $\stackrel{R}{R}$ & $\stackrel{\text { F }}{ }$ & \begin{tabular}{l}
$\infty$ \\
$\infty$ \\
$\infty$ \\
\multirow{-}{\sim}{}
\end{tabular} & 1 & $N$ & $\mathscr{ఠ}$ & $\mathbb{N}$ & $\stackrel{\sim}{ }$ & 1 & $\begin{array}{l}\mathscr{q} \\
\stackrel{O}{2}\end{array}$ & 1 & 1 \\
\hline 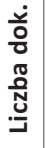 & 1 & 1 & 1 & 1 & 1 & 1 & 1 & $\stackrel{N}{N}$ & $r$ & $\sigma$ & 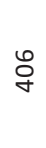 & 1 & 1 \\
\hline 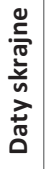 & $\begin{array}{l}\text { ¿ } \\
\text { ஸे } \\
\text { İ } \\
\text { ¿ }\end{array}$ & 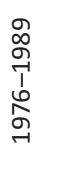 & 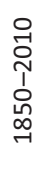 & فِ & 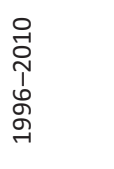 & 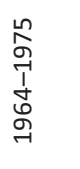 & 옹 & 공 & 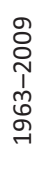 & 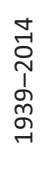 & 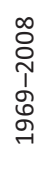 & 1 & 1 \\
\hline 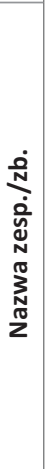 & 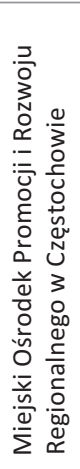 & 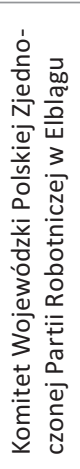 & $\begin{array}{l}\frac{\pi}{0} \\
\frac{\pi}{\tilde{N}} \\
\frac{\pi}{0} \\
\frac{\pi}{0} \\
\frac{0}{\tilde{N}} \\
n\end{array}$ & 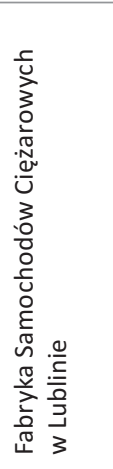 & 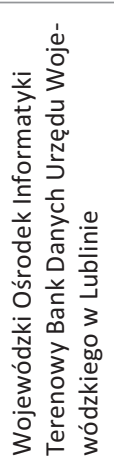 & 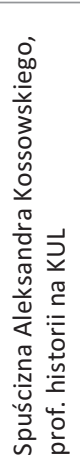 & 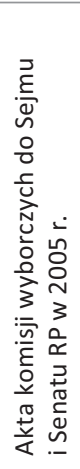 & 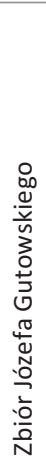 & 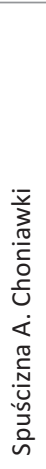 & $\begin{array}{l}3 \\
\frac{3}{E} \\
\frac{1}{4} \\
: \frac{0}{0} \\
\frac{0}{N}\end{array}$ & 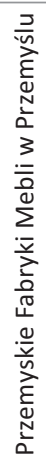 & 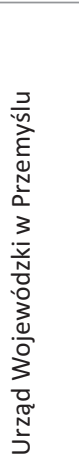 & 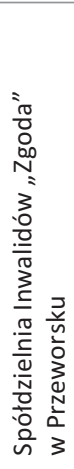 \\
\hline $\begin{array}{l}\frac{\dot{D}}{N} \\
\dot{D} \\
\frac{\dot{D}}{N} \\
\dot{N}\end{array}$ & $\frac{\vec{\emptyset}}{\stackrel{\infty}{\infty}}$ & 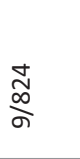 & $\frac{\text { Оे }}{\stackrel{-}{-1}}$ & 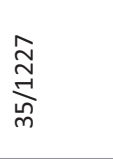 & 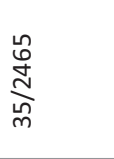 & 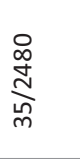 & 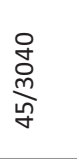 & \begin{tabular}{l}
0 \\
\multirow{\infty}{\infty}{} \\
유
\end{tabular} & 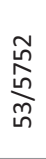 & 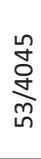 & 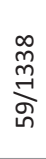 & 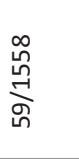 & 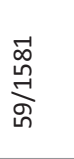 \\
\hline 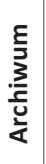 & 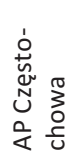 & $\begin{array}{l}\frac{00}{\sigma 0} \\
\frac{\sigma}{0} \\
\bar{W} \\
\frac{0}{<}\end{array}$ & $\begin{array}{l}\frac{3}{0} \\
\frac{2}{00} \\
\frac{20}{2} \\
z \\
4\end{array}$ & $\begin{array}{l}\frac{5}{0} \\
\frac{0}{3} \\
\frac{0}{4}\end{array}$ & $\begin{array}{l}\frac{5}{0} \\
\frac{0}{3} \\
\frac{0}{4}\end{array}$ & $\begin{array}{l}\frac{5}{\bar{a}} \\
\frac{3}{3} \\
\frac{a}{4}\end{array}$ & $\begin{array}{l}\frac{0}{0} \\
\frac{0}{0} \\
\frac{0}{\alpha}\end{array}$ & $\begin{array}{l}\frac{y}{0} \\
\frac{0}{0} \\
\frac{0}{\alpha}\end{array}$ & $\begin{array}{l}\frac{1}{2} \\
\frac{0}{2} \\
0 \\
0 \\
0 \\
\frac{1}{2}\end{array}$ & $\begin{array}{l}\frac{c}{0} \\
\frac{0}{N} \\
0 \\
0 \\
0 \\
\frac{0}{4}\end{array}$ & 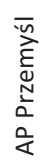 & 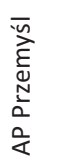 & 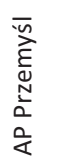 \\
\hline$\dot{9}$ & $\stackrel{\sim}{\sim}$ & $\stackrel{\sim}{\rightarrow}$ & ને & $\stackrel{\infty}{\sim}$ & $\underset{\neg}{\sigma}$ & $\stackrel{\sim}{v}$ & $\vec{\sim}$ & N & $\stackrel{\mathscr{N}}{\sim}$ & $\stackrel{d}{d}$ & $\stackrel{\Perp}{\sim}$ & $\ddot{N}$ & $\grave{\lambda}$ \\
\hline
\end{tabular}




\begin{tabular}{|c|c|c|c|c|c|c|c|c|c|c|c|c|c|c|}
\hline 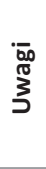 & 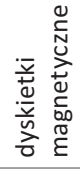 & & & & & & & & & 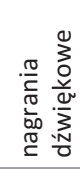 & $\begin{array}{l}\overrightarrow{\vec{E}} \\
\mathbb{v} \\
\frac{\vec{v}}{\omega}\end{array}$ & & & \\
\hline 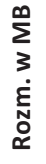 & 1 & 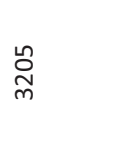 & $\begin{array}{l}\infty \\
0^{-} \\
\stackrel{+}{+}\end{array}$ & 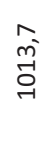 & 1 & 1 & 1 & 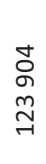 & $\begin{array}{c}m \\
e^{-} \\
\stackrel{2}{2}\end{array}$ & 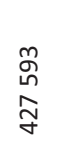 & 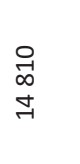 & $\underset{ }{\stackrel{ }{ }}$ & $\begin{array}{l}\stackrel{\text { O }}{\sim} \\
\stackrel{\text { I }}{\sim}\end{array}$ & : \\
\hline $\begin{array}{l}3 \\
0 \\
\frac{3}{0} \\
\frac{0}{0} \\
\stackrel{0}{N} \\
\stackrel{N}{J}\end{array}$ & 1 & $r$ & $\underset{\sim}{\stackrel{2}{0}}$ & in & $\neg$ & $r$ & ને & $\begin{array}{l}\stackrel{0}{1} \\
\text { ก } \\
\text { in }\end{array}$ & $\stackrel{\sim}{\sim}$ & 1 & $\widehat{6}$ & 1 & 。ㅇ & न \\
\hline 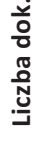 & 1 & 1 & 1 & 1 & $r$ & $r$ & ને & 1 & 1 & I & 1 & 1 & 옹 & न \\
\hline 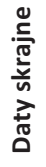 & 1 & $\stackrel{m}{\stackrel{n}{\sim}}$ & 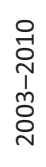 & 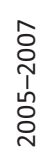 & $\begin{array}{l}\infty \\
\stackrel{0}{0} \\
\text { 1 } \\
\text { જे } \\
\stackrel{-}{-}\end{array}$ & 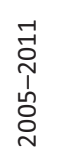 & & 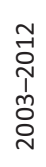 & $\begin{array}{l}m \\
\stackrel{n}{0} \\
\text { } \\
\stackrel{1}{\sim} \\
\stackrel{\sim}{N}\end{array}$ & 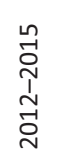 & 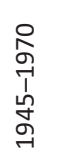 & 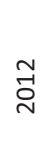 & 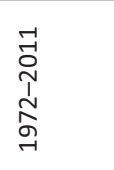 & $\begin{array}{l}n \\
\stackrel{2}{ } \\
\stackrel{1}{1} \\
-1 \\
\stackrel{0}{\sigma} \\
\sigma\end{array}$ \\
\hline 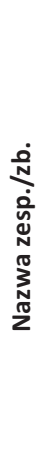 & 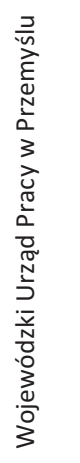 & 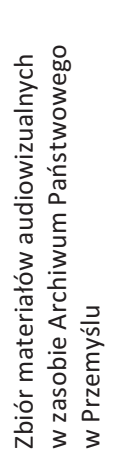 & 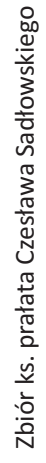 & 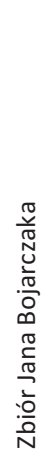 & 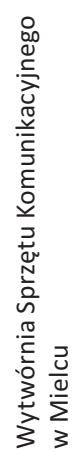 & 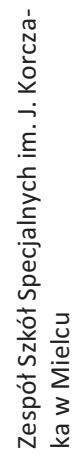 & 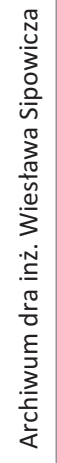 & 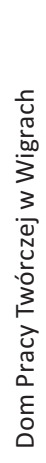 & 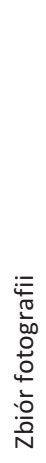 & 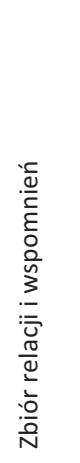 & 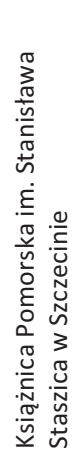 & 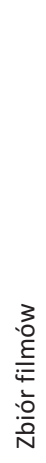 & 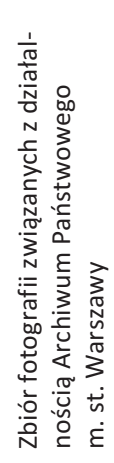 & 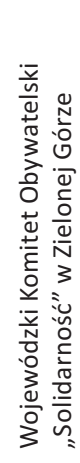 \\
\hline $\begin{array}{l}\frac{\dot{N}}{N} \\
\dot{\dot{d}} \\
\stackrel{N}{N} \\
\frac{N}{2}\end{array}$ & 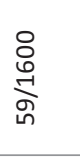 & 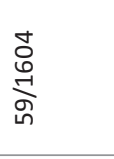 & $\underset{\substack{\infty \\
\sim}}{\stackrel{\sim}{\sim}}$ & 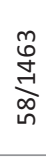 & 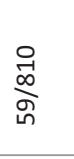 & 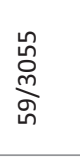 & $\begin{array}{l}\stackrel{\Omega}{n} \\
\stackrel{m}{n} \\
\text { } \\
\end{array}$ & $\frac{\stackrel{n}{n}}{\hat{n}}$ & $\frac{8}{8}$ & 엉 & 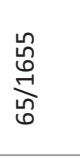 & 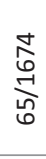 & 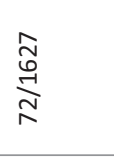 & $\underset{\infty}{\stackrel{\circ}{-}}$ \\
\hline 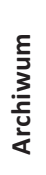 & 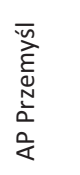 & 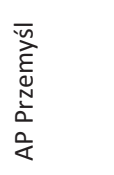 & 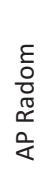 & $\begin{array}{l}\varepsilon \\
\frac{\varepsilon}{0} \\
\frac{0}{0} \\
\frac{1}{2} \\
\frac{\alpha}{\alpha}\end{array}$ & 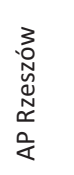 & 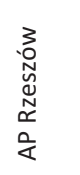 & 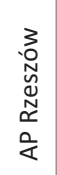 & 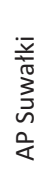 & 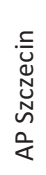 & $\begin{array}{l}\stackrel{c}{u} \\
\mathbb{N} \\
N \\
N \\
\stackrel{\alpha}{\alpha}\end{array}$ & 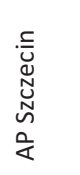 & 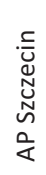 & 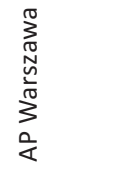 & 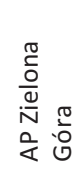 \\
\hline$\dot{9}$ & $\stackrel{\infty}{\sim}$ & ন & ○ & $\vec{m}$ & $\tilde{m}$ & $\stackrel{m}{m}$ & ウ & $\stackrel{\mathscr{n}}{m}$ & $\ddot{m}$ & $\hat{m}$ & $\stackrel{\infty}{m}$ & ని & 우 & $\vec{\gamma}$ \\
\hline
\end{tabular}

